\title{
An Assessment of the Current Day Impact of Various Materials Associated with the U. S. Nuclear Test Program in the Marshall Islands
}

William L. Robison, Victor E. Noshkin, Terry F. Hamilton Cynthia L. Conrado, and Kenneth T. Bogen

\section{May 1, 2001}

Law rence

Livermote

National

Laboratory
U.S. Department of Energy

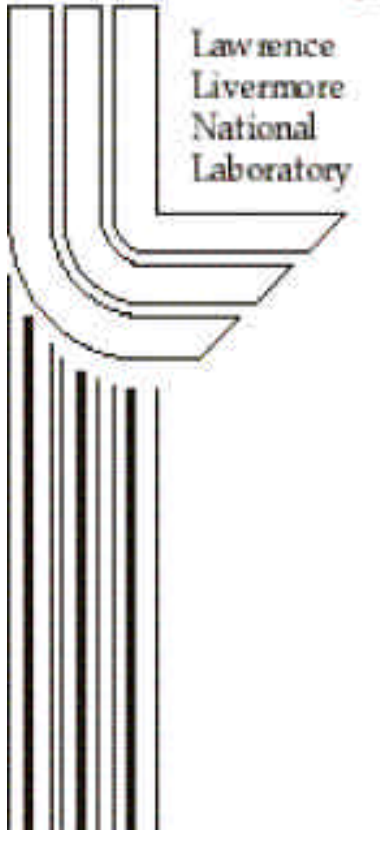




\section{DISCLAIMER}

This document was prepared as an account of work sponsored by an agency of the United States Government. Neither the United States Government nor the University of California nor any of their employees, makes any warranty, express or implied, or assumes any legal liability or responsibility for the accuracy, completeness, or usefulness of any information, apparatus, product, or process disclosed, or represents that its use would not infringe privately owned rights. Reference herein to any specific commercial product, process, or service by trade name, trademark, manufacturer, or otherwise, does not necessarily constitute or imply its endorsement, recommendation, or favoring by the United States Government or the University of California. The views and opinions of authors expressed herein do not necessarily state or reflect those of the United States Government or the University of California, and shall not be used for advertising or product endorsement purposes.

This work was performed under the auspices of the U. S. Department of Energy by the University of California, Lawrence Livermore National Laboratory under Contract No. W-7405-Eng-48.

This report has been reproduced directly from the best available copy.

Available electronically at http://www.doc.gov/bridge

Available for a processing fee to U.S. Department of Energy

And its contractors in paper from

U.S. Department of Energy

Office of Scientific and Technical Information

P.O. Box 62

Oak Ridge, TN 37831-0062

Telephone: (865) 576-8401

Facsimile: (865) 576-5728

E-mail: reports@adonis.osti.gov

Available for the sale to the public from

U.S. Department of Commerce

National Technical Information Service

5285 Port Royal Road

Springfield, VA 22161

Telephone: (800) 553-6847

Facsimile: (703) 605-6900

E-mail: orders@ntis.fedworld.gov

Online ordering: http://www.ntis.gov/ordering.htm

OR

Lawrence Livermore National Laboratory

Technical Information Department's Digital Library

http:/ / www.llnl.gov/tid/Library.html 


\title{
An Assessment of the Current Day Impact of Various Materials Associated with the U. S. Nuclear Test Program in the Marshall Islands
}

\author{
William L. Robison \\ Victor E. Noshkin \\ Terry F. Hamilton \\ Cynthia L. Conrado \\ Kenneth T. Bogen
}

May 1, 2001

\section{Lawrence Livermore National Laboratory}





\section{Table of Contents}

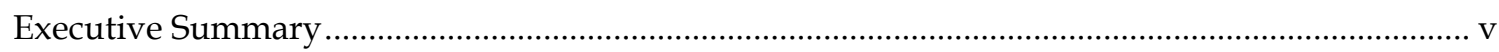

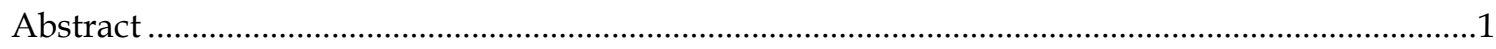

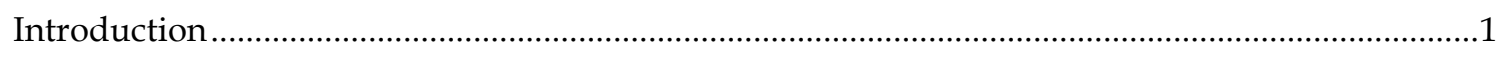

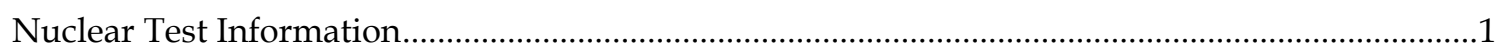

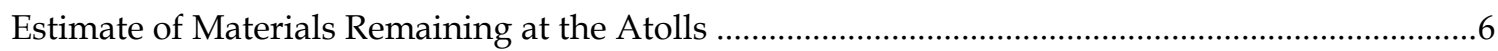

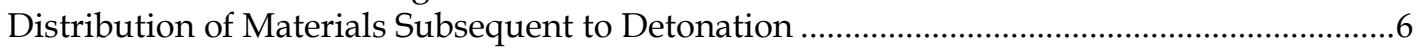

Fission Product Inventory Remaining at the Atolls ....................................................................

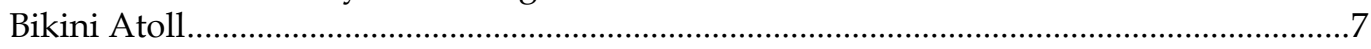

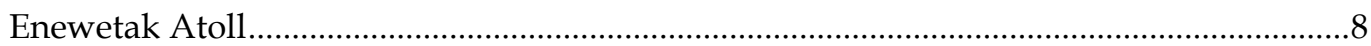

The Fraction of the ${ }^{137}$ Cs Fission Product Inventory Produced During

Testing That Remained at the Atolls .........................................................................................

The Concentration and Inventory of the Elements and Radionuclides Listed in Table 1

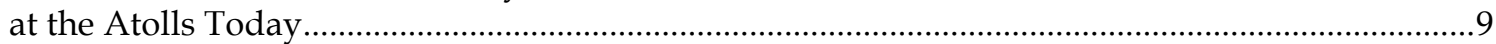

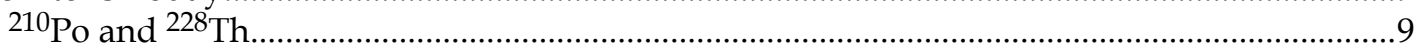

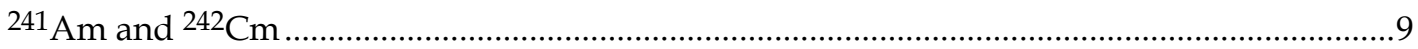

Stable S, As, Y, Rh, In, Ta, W, Au, and Tl ............................................................10

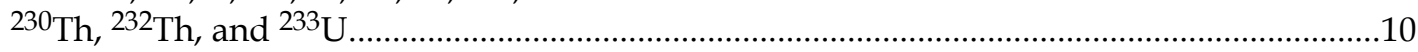

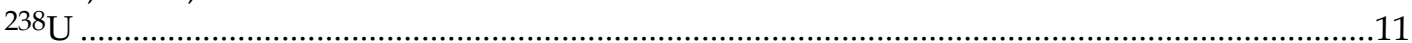

The Natural Uranium Concentration in Marine Corals ........................................................11

The Uranium Concentration in Soils and Sediments in the Marshall Islands..........................14

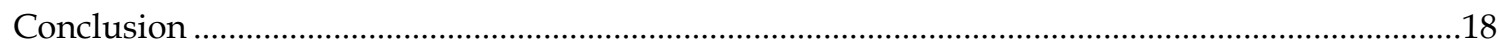

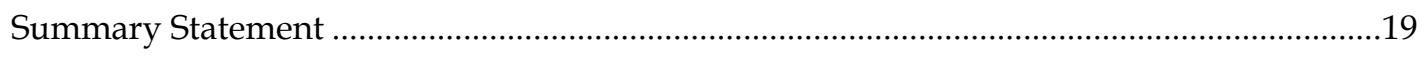

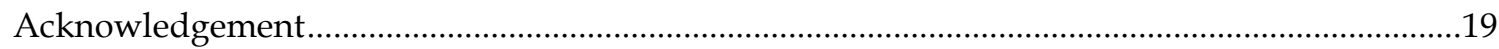

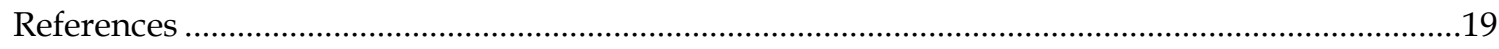

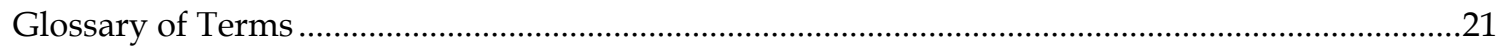

\section{List of Tables}

Table 1. The quantity of materials associated with the 67 nuclear tests conducted at or near Bikini and Enewetak Atolls.

Table 2. Nuclear test, with total yields, conducted at Bikini and Enewetak Atolls...........................

Table 3. Number of different types of nuclear tests conducted at Bikini and Enewetak Atolls. .....4

Table 4a. Bikini Atoll nuclear tests listed by year, name, test yield, series yield, and the series yield as a percentage of the cumulative yield at the atoll.

Table 4b. Enewetak Atoll nuclear tests listed by year, name, test yield, series yield, and the series yield as a percentage of the cumulative yield at the atoll. 
Table 5. The estimation of ${ }^{137} \mathrm{Cs}$ inventory at Bikini Atoll in 1954 .................................................

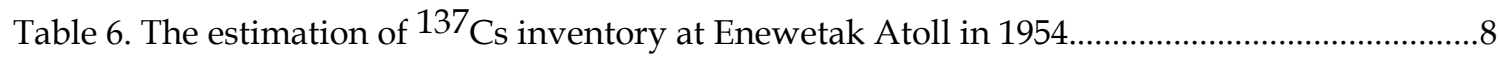

Table 7. The quantity of the materials in Table 1 that was available for local distribution at the atolls subsequent to detonation..........................................................................11

Table 8. The concentration of the test-related elements after detonation compared with the respective naturally occurring concentrations in coral soils. .............................................12

Table 9. The naturally occurring amount of ${ }^{230} \mathrm{Th}$ and ${ }^{232} \mathrm{Th}$ in the lagoons at Bikini and Enewetak Atolls compared with the test-related quantities..........................................12

Table 10. The mean concentration of $238 \mathrm{U}$ in corals from global locations.....................................13

Table 11. The mean concentration of ${ }^{238} \mathrm{U}$ in coral soil from Majuro, Kwajalein, Wotje,

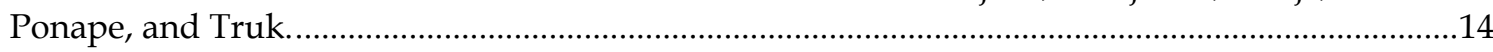

Table 12. The concentration of ${ }^{238} \mathrm{U}$ in soil and lagoon sediments at the

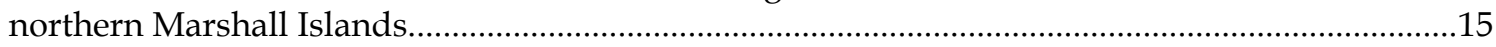

Table 13. The concentration of $238 \mathrm{U}$ in soil at Enewetak Atoll. ......................................................16

Table 14. The concentration of ${ }^{238} \mathrm{U}$ in the soil for atolls in the Marshall Islands...........................17 


\section{Executive Summary}

Different stable elements, and some natural and man-made radionuclides, were used as tracers or associated in other ways with nuclear devices that were detonated at Bikini and Enewetak Atolls as part of the U.S. nuclear testing program from 1946 through 1958. The question has been raised as to whether or not any of these materials dispersed by the explosions could be of sufficient concentration in either the marine environment or on the coral islands to be of a health concern to people living, or planning to live, on the atolls. This report addresses this concern.

An inventory of the materials involved during the test period was prepared and provided to us by the Office of Defense Program (DP) of the United States Department of Energy (DOE), and summarized in a letter from DP Assistant Secretary, Vic Reis to Dr. Paul Seligman, the DOE Deputy Assistant Secretary for Office of Health Programs, January 17, 1995. The quantities of materials abstracted from this letter, are shown in Table 1. These are the materials that the DOE and the Republic of the Marshall Islands ask to be evaluated.

The quantities of sulfur (S), arsenic (As), yttrium $(\mathrm{Y})$, tantalum $(\mathrm{Ta})$, gold $(\mathrm{Au})$, rhodium $(\mathrm{Rh})$, indium (Ir), tungsten (W), thallium (Tl) were used primarily as tracers for determining neutron energy and flux, and for other diagnostic purposes in the larger yield multistate devices. The neutrons bombarding these materials produced short-lived radioactive isotopes of each of the elements that could be measured for diagnostic purposes. The natural and man-made radioactive isotopes were used in various ways in the larger yield multi-stage devices and in some of the smaller yield tests.

Based on discussions with physicists and radiochemists at LLNL, it is reasonable to assume that these materials would be distributed in a similar manner as the fission products subsequent to detonation.

Consequently, we have estimated the amount of the fission product cesium- $137\left({ }^{137} \mathrm{Cs}\right)$ that is present at the atolls today, decay corrected the results to 1954, and then doubled this quantity to account for any loss in the intervening years by environmental processes to produce ${ }^{137} \mathrm{Cs}$ inventory at the atolls in 1954. We then determined the total amount of ${ }^{137} \mathrm{Cs}$ produced during the nuclear tests at the atolls. We used $50 \%$ of the total yield at Bikini Atoll and $63 \%$ of the total yield at Enewetak as the fission yields, and then used the conversion factor of 5.9 PBq of ${ }^{137}$ Cs per $\mathrm{mt}$ of fission given in UNSCEAR (2000) to calculate the total ${ }^{137}$ Cs inventory produced. The ratio of the 1954 inventory of ${ }^{137} \mathrm{Cs}$ at the atoll to the ${ }^{137} \mathrm{Cs}$ inventory produced during the test program is 0.0029 $(0.29 \%)$. This fraction was increased by $50 \%$ to $0.0042(0.42 \%)$ to account for any distribution deviations of the more retractory elements and then applied to the materials listed in Table 1 to estimate the amount of material remaining at the atolls. An estimate of this fraction, based on the strontrium-90 $\left({ }^{90} \mathrm{Sr}\right)$ inventory in Enewetak lagoon, is $0.12 \%$ less by nearly a factor of four than the $0.42 \%$ based on the ${ }^{137} \mathrm{Cs}$ analysis we used.

These fractions are consistent with the atmospheric portioning listed in UNSCEAR (2000) for all nuclear testing. They estimate 77\% of the total yield was distributed to the stratosphere, $8.5 \%$ to the troposphere, and $15 \%$ to the regional/local domains. Only a small fraction of the regional/local component of $15 \%$ would be dispersed on a local scale the size of the atolls.

Some conservative assumptions were made in the process of these calculations. For example, 10 to $20 \%$ of the stable elements would have been activated to other short-lived isotopes, but we used the total amount in Table 1 knowing it is an overestimate of the amount of material at the atolls, similarly, a significant fraction of the Uranium-238 $\left({ }^{238} \mathrm{U}\right)$ would have fissioned, but we have again used the total amount knowing it is over estimated.

To determine the concentration of these materials at the atolls, the dispersed quantity was distributed over one half the area of both Bikini and Enewetak Atolls, and to a depth of 20 $\mathrm{cm}$ in island soils. The resulting concentrations of the materials are extremely low and range from nanograms per $\mathrm{g}$ soil to femtograms per $\mathrm{g}$ of soil. Moreover, the natural concentrations of these materials in carbonate soils of marine 
origin are higher by factors ranging from 1,500 to 9 billion than those resulting from the nuclear testing program.

By far the largest quantity of material used in the testing program was ${ }^{238} \mathrm{U}(66,980$ $\mathrm{kg}$ ), which is higher by factors ranging from 60 to 880,000 than all of the other listed materials. Extensive data on the concentration of uranium
(U) at atolls in the Marshall Islands show that the $U$ concentration is essentially the same at all atolls, and no increase in $U$ is measurable as was estimated in our analysis.

Consequently, based on the information provided, we conclude that the concentration of these materials in the atoll environment pose no adverse health effects to humans. 


\title{
An Assessment of the Current Day Impact of Various Materials Associated with the U. S. Nuclear Test Program in the Marshall Islands
}

\author{
William L. Robison, Victor E. Noshkin, Terry F. Hamilton, Cynthia L. Conrado, and Kenneth T. Bogen
}

\begin{abstract}
Different stable elements, and some natural and man-made radionuclides, were used as tracers or associated in other ways with nuclear devices that were detonated at Bikini and Enewetak Atolls as part of the U.S. nuclear testing program from 1946 through 1958. The question has been raised whether any of these materials dispersed by the explosions could be of sufficient concentration in either the marine environment or on the coral islands to be of a health concern to people living, or planning to live, on the atolls. This report addresses that concern.
\end{abstract}

An inventory of the materials involved during the test period was prepared and provided to us by the Office of Defense Programs (DP) of the United States Department of Energy (DOE). The materials that the DOE and the Republic of the Marshall Islands (RMI) ask to be evaluated are - sulfur, arsenic, yttrium, tantalum, gold, rhodium, indium, tungsten, thallium, thorium-230,232 $(230,232 \mathrm{Th})$, uranium-233,238 $(233,238 \mathrm{U})$, polonium-210 $\left({ }^{210} \mathrm{Po}\right)$, curium-232 $\left({ }^{232} \mathrm{Cu}\right)$, and americium-241 $\left({ }^{241} \mathrm{Am}\right)$. The stable elements were used primarily as tracers for determining neutron energy and flux, and for other diagnostic purposes in the larger yield, multistage devices.

It is reasonable to assume that these materials would be distributed in a similar manner as the fission products subsequent to detonation. A large inventory of fission product and uranium data was available for assessment. Detailed calculations show only a very small fraction of the fission products produced during the entire test series remain at the test site atolls.

Consequently, based on the information provided, we conclude that the concentration of these materials in the atoll environment pose no adverse health effects to humans.

\section{Introduction}

Different stable elements, and some natural and man-made radionuclides, were associated with nuclear devices detonated at Bikini and Enewetak Atolls as part of the U.S. nuclear testing program from 1946 through 1958. These materials were used for determining the neutron energy spectrum and flux, and for other diagnostic purposes. The question has been raised as to whether or not any of these materials dispersed by the explosions could be of sufficient concentration in either the marine environment or on the coral islands to be of a health concern to people living, or planning to live, on the atolls. This report addresses this concern.

An inventory of the materials involved during the test period was prepared and provided to us by the Office of Defense Programs of the United States Department of Energy, and summarized in a letter from DP Assistant Secretary, Vic Reis to Dr. Paul Seligman, the DOE Deputy Assistant Secretary for the Office of Health Programs, January 17, 1995. The quantities of materials abstracted from this letter are shown in Table 1. These are the materials that the DOE and the Republic of the Marshall Islands ask to be evaluated.

\section{Nuclear Test Information}

The nuclear tests and their explosive yields (TNT equivalent) conducted at the Bikini and Enewetak Atolls are listed in Table 2. The total yields are divided into three categories, those greater than 0.49 million tons $(\mathrm{mt})$, or 490 kilo tons $(\mathrm{kt})$, those between $0.1 \mathrm{mt}(100 \mathrm{kt})$ and $0.49 \mathrm{mt}(490 \mathrm{kt})$, and those less than $0.1 \mathrm{mt}$ (100 kt). 
Table 1. The quantity of materials associated with the 67 nuclear tests conducted at or near Bikini and Enewetak Atolls. ${ }^{\mathrm{a}}$

\begin{tabular}{lrc}
\hline Material & Quantity $(\mathrm{g})$ & Half-life \\
\hline Sulfur & 727,000 & Stable \\
Arsenic & 75.7 & Stable \\
Yttrium & 236 & Stable \\
Rhodium & $<200$ & Stable \\
Indium & 2,660 & Stable \\
Tantalum & 88.3 & Stable \\
Tungsten & 3,100 & Stable \\
Gold & 500 & Stable \\
Thallium & 155,000 & Stable \\
Polonium-210 & 1.09 & $138.4 \mathrm{~d}$ \\
Thorium-228 & 0.0023 & $1.912 \mathrm{y}$ \\
Thorium-230 & 1,494 & $7.7 \times 10^{4} \mathrm{y}$ \\
Thorium-232 & $1,080,000$ & $1.4 \times 10^{10} \mathrm{y}$ \\
Uranium-233 & 1,094 & $1.62 \times 10^{5} \mathrm{y}$ \\
Uranium-238 & $66,980,000$ & $4.47 \times 10^{9} \mathrm{y}$ \\
Americium-241 & 0.29 & $433 \mathrm{y}$ \\
Curium-242 & 1.8 & $162.94 \mathrm{~d}$
\end{tabular}

a These are the quantities of materials used at Bikini and Enewetak Atolls during the testing program. The bulk of the materials were released during and after 1954. These do not represent the quantities of test materials remaining today.

At Bikini Atoll almost $98 \%$ of the entire yield was from large-yield nuclear tests that ranged from 0.5 to $15 \mathrm{mt}$. At Enewetak Atoll about $92 \%$ of the entire yield was from tests greater than $0.5 \mathrm{mt}$. About $2 \%$ of the gross yield was from tests between 0.1 and $0.49 \mathrm{mt}$ at Bikini and about $6 \%$ at Enewetak. Low yield tests, $<0.1$ $\mathrm{mt}$, accounted for about $0.3 \%$ of the total yield at Bikini and $1.9 \%$ at Enewetak. Consequently, the large mt-size devices are of critical importance in assessing the potential dispersion at the atolls of the materials listed in Table 1, and especially the stable elements, which were primarily used as tracers in these devices. The lower yield tests could have produced a more localized deposition of $U$, plutonium-239+240 $\left({ }^{239+240} \mathrm{Pu}\right)$, ${ }^{238} \mathrm{Pu}$, americium-241 $\left({ }^{241} \mathrm{Am}\right)$, and fission products, but a large fraction of the materials was still distributed over relatively large areas compared to the size of any ground-zero island.

The types of tests at the two atolls are listed in Table 3. A total of 36 out of the 67 tests conducted at atolls were on barges mostly over deep water. Two tests were exploded on barges on the reef, five were air drops, and three were underwater shots. Most of any materials shown in Table 1 that was included in the over water tests or the atmospheric tests would not have been deposited directly onto islands at the atolls.

There were 13 tower shots $(60-\mathrm{m}$ or 90-m towers), all at Enewetak, that were generally over land surfaces or the immediate reef near islands. Eight tests were on platforms over land surfaces.

The year of each test, the test names, the test yields, the annual yields, and the annual yield as a percentage of the total yield are listed in Tables $4 \mathrm{a}$ and $4 \mathrm{~b}$ for Bikini and Enewetak Atolls, respectively. At Bikini Atoll nearly 61\% of the total yield was the result of the Castle series of tests in 1954, with another $24 \%$ in the 1956 Redwing test series. The 1958 Hardtack I series of tests accounted for the remaining $15-16 \%$.

The distribution of tests at Enewetak covered a few more years with about $51 \%$ of the 
Table 2. Nuclear test, with total yields, conducted at Bikini and Enewetak Atolls. ${ }^{a}$

\begin{tabular}{|c|c|c|c|c|c|}
\hline \multicolumn{2}{|c|}{11 Tests $>0.49 \mathrm{mt}$} & \multicolumn{2}{|c|}{$\begin{array}{l}\text { Bikini Atoll (24 tests) } \\
6 \text { Tests } 0.1-0.49 \mathrm{mt}\end{array}$} & \multicolumn{2}{|c|}{7 Tests $<0.1 \mathrm{mt}$} \\
\hline Test & Yield & Test & Yield & Test & Yield \\
\hline Bravo & 15 & Redwood & 0.412 & Sycamore & 0.092 \\
\hline Yankee & 13.5 & Flathead & 0.365 & Juniper & 0.065 \\
\hline Romeo & 11 & Aspen & 0.319 & Nutmeg & 0.0251 \\
\hline Poplar & 9.3 & Cedar & 0.220 & Able & 0.021 \\
\hline Union & 6.9 & Maple & 0.213 & Baker & 0.021 \\
\hline Tewa & 5.0 & Koon & 0.11 & Hickory & 0.014 \\
\hline Navajo & 4.5 & & & Yucca & 0.0017 \\
\hline Cherokee & 3.8 & & & & \\
\hline Zuni & 3.5 & & & & \\
\hline Butternut & 1.36 & & & & \\
\hline Dakota & 1.1 & & & & \\
\hline \multirow[t]{2}{*}{ Subtotal (mt) } & 74.96 & & 1.639 & & 0.2398 \\
\hline & & & & Total & $76.84 \mathrm{mt}$ \\
\hline \multicolumn{6}{|c|}{ Enewetak Atoll (43 tests) } \\
\hline \multicolumn{2}{|l|}{9 Tests $>0.49 \mathrm{mt}$} & \multicolumn{2}{|c|}{7 Tests $0.1-0.49 \mathrm{mt}$} & \multicolumn{2}{|c|}{27 Tests $<0.1 \mathrm{mt}$} \\
\hline Test & Yield & Test & Yield & Test & Yield \\
\hline $\begin{array}{l}\text { Mike } \\
\text { Oak } \\
\text { Pine } \\
\text { Apache } \\
\text { Nectar } \\
\text { Walnut } \\
\text { Koa } \\
\text { Elder } \\
\text { King }\end{array}$ & $\begin{array}{c}10.4 \\
8.9 \\
2.0 \\
1.85 \\
1.69 \\
1.45 \\
1.37 \\
0.88 \\
0.50\end{array}$ & $\begin{array}{l}\text { Dogwood } \\
\text { Mohawk } \\
\text { Yellowwood } \\
\text { Pisonia } \\
\text { Huron } \\
\text { George } \\
\text { Olive }\end{array}$ & $\begin{array}{l}0.397 \\
0.360 \\
0.330 \\
0.255 \\
0.250 \\
0.225 \\
0.202\end{array}$ & $\begin{array}{l}\text { Dog } \\
\text { Butternut } \\
\text { Magnolia } \\
\text { Yoke } \\
\text { Easy } \\
\text { Item } \\
\text { LaCross } \\
\text { Xray } \\
\text { Zebra } \\
\text { Cactus } \\
\text { Inca } \\
\text { Rose } \\
\text { Erie } \\
\text { Seminole } \\
\text { Tobacco } \\
\text { Linden } \\
\text { Wahoo } \\
\text { Blackfoot } \\
\text { Umbrella } \\
\text { Holly } \\
\text { Sequoia } \\
\text { Osage } \\
\text { Kickapoo } \\
\text { Yuma } \\
\text { Fig } \\
\text { Scaevola } \\
\text { Quince }\end{array}$ & $\begin{array}{l}0.081 \\
0.081 \\
0.057 \\
0.049 \\
0.047 \\
0.0455 \\
0.040 \\
0.037 \\
0.018 \\
0.018 \\
0.0152 \\
0.015 \\
0.0149 \\
0.0137 \\
0.0116 \\
0.011 \\
0.009 \\
0.008 \\
0.008 \\
0.0059 \\
0.0052 \\
0.0017 \\
0.00149 \\
0.00019 \\
0.00002 \\
0 \\
0\end{array}$ \\
\hline Subtotal (mt) & 29.04 & & 2.019 & Total & $\begin{array}{c}0.5944 \\
31.65 \mathrm{mt}\end{array}$ \\
\hline
\end{tabular}

a The significant figures are as quoted in Simon and Robison (1997). Total yield refers to the total energy released during the fission and fusion processes. 
Table 3. Number of different types of nuclear tests conducted at Bikini and Enewetak Atolls.

\begin{tabular}{lccc}
\hline Type of test & Bikini Atoll & Enewetak Atoll & Total \\
\hline Barge over deep water & 16 & 19 & 35 \\
Barge over shallow water & 1 & 0 & 1 \\
Barge on reef & 0 & 2 & 2 \\
Platform on island & 3 & 5 & 8 \\
Air drop & 3 & 2 & 5 \\
Underwater & 1 & 2 & 3 \\
Tower & $\underline{0}$ & $\underline{13}$ & $\underline{43}$ \\
& Total & 24 & 67 \\
\hline
\end{tabular}

Table 4a. Bikini Atoll nuclear tests listed by year, name, test yield, series yield, and the series yield as a percentage of the cumulative yield at the atoll.

\begin{tabular}{|c|c|c|c|c|c|}
\hline Year & Test name & & Yield, kt & Series yield, kt & $\%$ \\
\hline \multicolumn{6}{|c|}{ Crossroads Series } \\
\hline 1946 & Able & & 21 & & \\
\hline 1946 & Baker & & 21 & 42 & 0.05 \\
\hline \multicolumn{6}{|c|}{ Castle Series } \\
\hline 1954 & Bravo & & 15,000 & & \\
\hline 1954 & Romeo & & 11,000 & & \\
\hline 1954 & Union & & 6,900 & & \\
\hline 1954 & Yankee & & 13,500 & & \\
\hline 1954 & Koon & & 110 & 46,510 & 60.6 \\
\hline \multicolumn{6}{|c|}{ Redwing Series } \\
\hline 1956 & Tewa & & 5,000 & & \\
\hline 1956 & Cherokee & & 3,800 & & \\
\hline 1956 & Flathead & & 365 & & \\
\hline 1956 & Dakota & & 1,100 & & \\
\hline 1956 & Navaho & & 4,500 & & \\
\hline 1956 & Zuni & & 3,500 & 18,265 & 23.8 \\
\hline \multicolumn{6}{|c|}{ Hardtack I Series } \\
\hline 1958 & Fir & & 1,300 & & \\
\hline 1958 & Sycamore & & 130 & & \\
\hline 1958 & Aspen & & 320 & & \\
\hline 1958 & Cedar & & 220 & & \\
\hline 1958 & Poplar & & 9,300 & & \\
\hline 1958 & Maple & & 195 & & \\
\hline 1958 & Redwood & & 415 & & \\
\hline 1958 & Nutmeg & & 24 & & \\
\hline 1958 & Hickory & & 13 & & \\
\hline 1958 & Juniper & & 62 & & \\
\hline \multirow[t]{2}{*}{1958} & Yucca ${ }^{a}$ & & 1.7 & 11,981 & 15.6 \\
\hline & & Total & 76,798 & 76,798 & 100.0 \\
\hline
\end{tabular}

a Test west of Bikini Atoll. 
Table 4b. Enewetak Atoll nuclear tests listed by year, name, test yield, series yield, and the series yield as a percentage of the cumulative yield at the atoll.

\begin{tabular}{|c|c|c|c|c|}
\hline Year & Test name & Yield, kt & Series yield, kt & $\%$ \\
\hline \multicolumn{5}{|c|}{ Sandstone Series } \\
\hline 1948 & X-Ray & 37 & & \\
\hline 1948 & Yoke & 49 & & \\
\hline 1948 & Zebra & 18 & 104 & 0.329 \\
\hline \multicolumn{5}{|c|}{ Greenhouse Series } \\
\hline 1951 & Easy & 47 & & \\
\hline 1951 & Item & 45.5 & & \\
\hline 1951 & George & 225 & & \\
\hline 1951 & Dog & 81 & 398.5 & 1.26 \\
\hline \multicolumn{5}{|c|}{ Ivy Series } \\
\hline 1952 & Mike & 10,400 & & \\
\hline 1952 & King & 500 & 10,900 & 34.4 \\
\hline \multicolumn{5}{|c|}{ Castle Series } \\
\hline 1954 & Nectar & 1,690 & 1,690 & 5.34 \\
\hline \multicolumn{5}{|c|}{ Redwing Series } \\
\hline 1956 & Apache & 1,850 & & \\
\hline 1956 & Huron & 250 & & \\
\hline 1956 & Seminole & 13.7 & & \\
\hline 1956 & Mohawk & 360 & & \\
\hline 1956 & Kickapoo & 1.49 & & \\
\hline 1956 & Inca & 15.2 & & \\
\hline 1956 & Yuma & 0.19 & & \\
\hline 1956 & Lacrosse & 40 & & \\
\hline 1956 & Erie & 14.9 & & \\
\hline 1956 & Blackfoot & 8 & & \\
\hline 1956 & Osage & 1.7 & 2,555 & 8.07 \\
\hline \multicolumn{5}{|c|}{ Hardtack I Series } \\
\hline 1958 & Коа & 1,370 & & \\
\hline 1958 & Yellowwood & 330 & & \\
\hline 1958 & Tobacco & 11.6 & & \\
\hline 1958 & Walnut & 1,450 & & \\
\hline 1958 & Elder & 880 & & \\
\hline 1958 & Dogwood & 397 & & \\
\hline 1958 & Olive & 202 & & \\
\hline 1958 & Pine & 2,000 & & \\
\hline 1958 & Cactus & 18 & & \\
\hline 1958 & Scaevola & 0 & & \\
\hline 1958 & Pisonia & 255 & & \\
\hline 1958 & Quince & 0 & & \\
\hline 1958 & Fig & 0.2 & & \\
\hline 1958 & Butternut & 81 & & \\
\hline 1958 & Holly & 5.9 & & \\
\hline 1958 & Magnolia & 57 & & \\
\hline 1958 & Rose & 15 & & \\
\hline 1958 & Linden & 11 & & \\
\hline 1958 & Sequoia & 5.2 & & \\
\hline 1958 & Umbrella & 8 & & \\
\hline 1958 & Oak & 8,900 & & \\
\hline \multirow[t]{2}{*}{1958} & Wahoo & 9 & 16,016 & 50.6 \\
\hline & Total & 31,654 & 31,654 & 100.0 \\
\hline
\end{tabular}


total yield resulting from the 1958 series. The 1952 series accounted for another $34 \%$. The remaining $15 \%$ was distributed among the 1948 , 1951, and 1954 test series.

The estimated total fission yield at Bikini Atoll is 50\% of the total or $38.4 \mathrm{mt}$ and at Enewetak $63 \%$ of the total or $19.9 \mathrm{mt}$. The production of the fission product cesium-137 $\left({ }^{137} \mathrm{Cs}, \mathrm{t}_{1 / 2}=30.1 \mathrm{y}\right)$ is $5.9 \mathrm{PBq}$ per $\mathrm{mt}$ of fission
(UNSCEAR, 2000) leading to a production at Bikini Atoll of $227 \mathrm{PBq}\left(2.27 \times 10^{17} \mathrm{~Bq}\right)$, and at Enewetak Atoll of $118 \mathrm{PBq}\left(1.18 \times 10^{17} \mathrm{~Bq}\right)$ for a total of $3.45 \times 10^{17} \mathrm{~Bq}$. The ${ }^{90} \mathrm{Sr},\left(\mathrm{t}_{1 / 2}=28.5 \mathrm{y}\right)$ production is $3.9 \mathrm{PBq}$ per $\mathrm{mt}$ of fission (UNSCEAR, 2000). This leads to a production of $150 \mathrm{PBq}\left(1.50 \times 10^{17} \mathrm{~Bq}\right)$ at Bikini and $78 \mathrm{PBq}$ $\left(0.78 \times 10^{17} \mathrm{~Bq}\right)$ at Enewetak for a total of $2.28 \times 10^{17} \mathrm{~Bq}$ for both atolls.

\section{Estimate of Materials Remaining at the Atolls}

\section{Distribution of Materials Subsequent to Detonation}

The quantities of S, As, Y, Ta, Au, Rh, Ir, $\mathrm{W}$, and $\mathrm{Tl}$ were used primarily as tracers for determining neutron energy and flux, and for other diagnostic purposes in the larger yield multistage devices. The neutrons bombarding these materials produced short-lived radioactive isotopes of each of the elements that could be measured for diagnostic purposes. The natural and man-made radioactive isotopes were used for various purposes in the larger yield multistage devices and in some of the smaller yield tests.

Despite the complexity of the chemical and physical processes attending a nuclear explosion above ground or over water, there are certain generalized patterns of debris behavior. The intense heat created at the time of detonation creates plasma that includes the fission and activation products, unreacted fuel elements, tracers and other inert components from the surrounding environment. All materials are intermixed in the stem and cloud as they rise and expand. Any unreacted tracer elements or isotopes are assumed to have the same general spatial distribution as the fission products, such as ${ }^{137} \mathrm{Cs}$ and ${ }^{90} \mathrm{Sr}$, within the forming fireball. Physicists and radiochemists (Moody, Lougheed; private communication) at Lawrence Livermore National Laboratory (LLNL) agree this is a reasonable assumption for comparative purposes. The cloud then rises rapidly to high elevations, and expands and moves in the general direction of any prevailing winds found at different altitudes. Cooling and condensation begin within the cloud shortly after detonation. The tracer elements and isotopes, along with fission and activation products, unspent fuel, and other vaporized materials, recondense as particles or attach to particles of different sizes that eventually settle from the atmospheric reservoirs at different rates as "fallout" to the earth's surface. Many refractory elements would condense out of the cloud at an early time, but this would occur when the largest portion of the debris-cloud was outside the perimeter of the atolls and over the ocean. These elements would more closely follow the fallout pattern of $239+240 \mathrm{Pu}$ that, in turn, mimics the global fallout pattern of lesser refractory fission products, ${ }^{137} \mathrm{Cs}$ and ${ }^{90} \mathrm{Sr}$.

Glasstone (1962) estimated that for the total quantity of ${ }^{90} \mathrm{Sr}$ generated during the tests by the U. S. between 1946 and 1958, 6\% was introduced to the mesosphere, $45 \%$ to the lower stratosphere, $9 \%$ to the troposphere, and $40 \%$ was local fallout that was deposited within days to regions of the north Pacific Ocean. Eightythree percent of the ${ }^{90} \mathrm{Sr}$ introduced to the troposphere also fell into the Pacific surface waters within a few weeks. This predicted excess local fallout delivered to the Pacific was close to the measured excess (above global fallout) inventory measured during 1972-1973 in the Pacific Ocean from water samples collected during the Geochemical Oceans Sections (GEOSECS) program (Bowen et al., 1980). We can then accept that the estimated amounts delivered to the other atmospheric reservoirs are reasonable. Moreover, the UNSCEAR (2000) report provides estimates for the atmospheric portioning for the fission yields from all countries. They estimate that $76 \%$ of the fission 
yield was distributed to the stratosphere, $8.4 \%$ to the troposphere, and $15 \%$ to local and regional environments. The local fallout component is a small fraction of the total $15 \%$ regional fallout component for areas as small as atolls.

Consequently, most of the materials volatilized during the explosions, including the tracers listed in Table 1, were deposited over the Pacific and other world oceans and global land masses. Indeed, the local fallout is the source responsible for the radioactive contamination at the atolls, but the amount represents only a small fraction of the total amount produced during the test series and of the estimated local and regional component. Likewise, only a comparable small fraction of any surviving tracer material would have been deposited in the atoll's environment during testing of the large-yield devices.

In summary, a reasonable conclusion is that the elements in Table 1 are distributed the same as the fission products after a detonation. Physicists and radiochemists (Moody, Lougheed; private communication) at LLNL agree this is a reasonable assumption with which to compare current inventories at the atolls.

\section{Fission Product Inventory Remaining at the Atolls}

The ${ }^{137}$ Cs fission product inventory in soils at Bikini and Enewetak Atolls can be estimated from data generated over the past 20 years as part of the Dose Assessment and Radioecology Program conducted by LLNL for the Department of Energy (DOE).

Bikini Atoll The estimate of the ${ }^{137} \mathrm{Cs}$ inventory as of 1987 on the islands is based on soil profiles collected to a depth of $60 \mathrm{~cm}$, which accounts for more than $98 \%$ of the ${ }^{137} \mathrm{Cs}$ inventory from the soil surface to the ground water. The relevant data are shown in Table 5.

The mean value of the ${ }^{137} \mathrm{Cs}$ concentration to $60-\mathrm{cm}$ depth is listed in column 3 of Table 5 for Bikini Island (Robison et al., 1997), Eneu Island, and the remaining islands at the atoll (Robison et al., 1988). The mean ${ }^{137} \mathrm{Cs}$ concentration was then multiplied by the land area for Bikini Island, Eneu Island, and the remaining islands to generate the ${ }^{137} \mathrm{Cs}$ inventory (column 4, Table 5).

Table 5. The estimation of ${ }^{137}$ Cs inventory at Bikini Atoll in 1954.

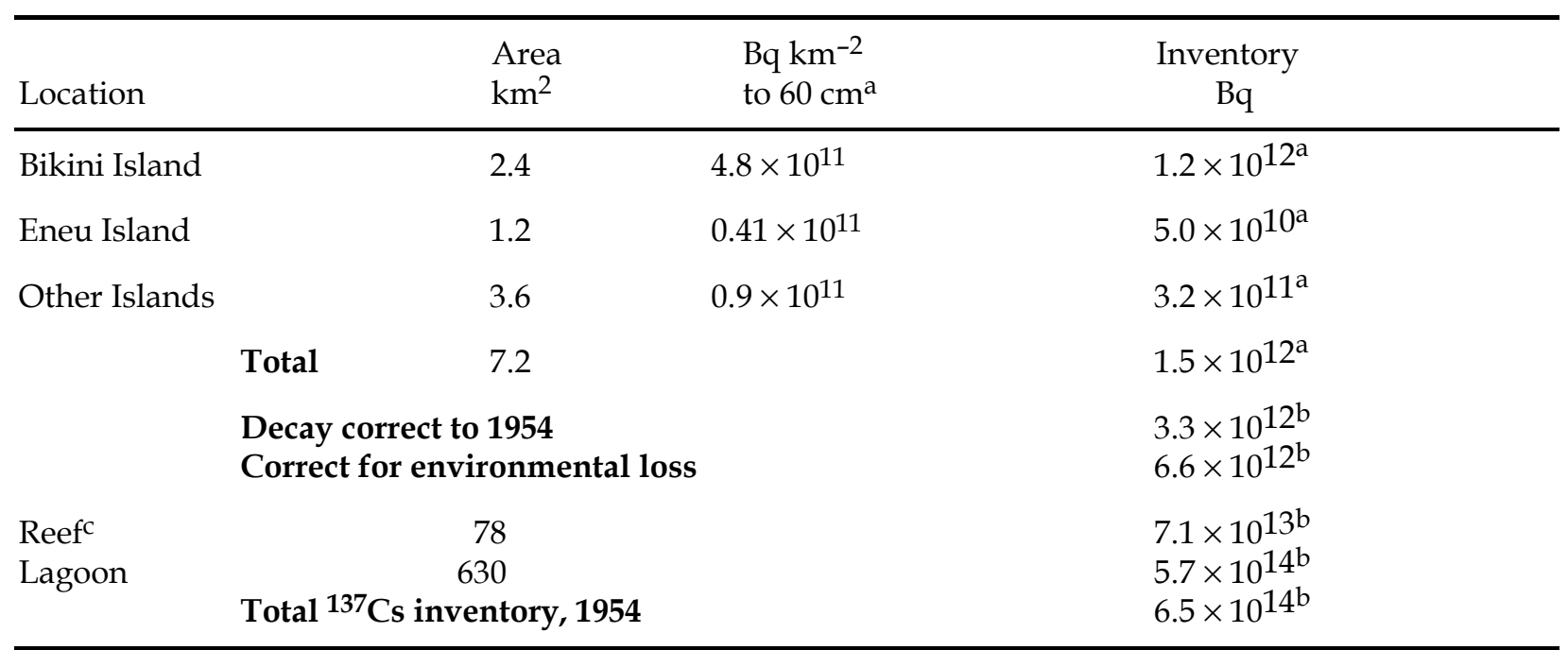

a Mean value of all data decay corrected to 1987.

b As of 1954 (the midyear of the major test series at Bikini).

c Area other than islands. 
The 1987 inventory was decay corrected to 1954 . About $60 \%$ of the total nuclear yield at Bikini Atoll occurred during the 1954 test series (Table 4a). Another 39\% occurred in the 1956 and 1958 test series, and only $0.05 \%$ occurred prior to 1954. Thus, decay-correcting the present day levels to 1954 provides a conservative estimate (i.e., probably overestimates the actual ${ }^{137}$ Cs deposition) of the quantities deposited to the atoll during testing.

Cesium-137 has always been measured in groundwater samples from the atolls subsequent to the nuclear testing. Thus, ${ }^{137} \mathrm{Cs}$ is continually removed at some rate from the soil to the groundwater. Although this rate of loss has not been established, we doubled the decaycorrected ${ }^{137} \mathrm{Cs}$ inventory to account for any loss by environmental processes during the intervening years such as leaching of the ${ }^{137} \mathrm{Cs}$ to the groundwater during periods of high rainfall. The resulting ${ }^{137} \mathrm{Cs}$ inventory on island land masses at Bikini Atoll is $6.6 \times 10^{12} \mathrm{~Bq}$.

Deposition during the detonations at the atoll occurred on the reef and in the lagoon as well as on land. Most of the ${ }^{137} \mathrm{Cs}$ deposited in these areas has since mixed with the Pacific Ocean. However, the inventory deposited initially over these areas must be included to assess the total inventory at the atolls in 1954.
Thus, the inventory estimated for the Bikini land masses was multiplied by the ratio of reef area to the island land area, and the lagoon area to the land area, to generate a total estimated ${ }^{137} \mathrm{Cs}$ inventory in 1954 of $6.5 \times 10^{14} \mathrm{~Bq}$.

Enewetak Atoll A similar procedure was adopted for Enewetak Atoll. The southern islands were grouped because they all have similar ${ }^{137}$ Cs concentrations (Robison, this report); the northern islands formed the second group (Robison, this report); and, the northern islands formed the third group (Robison, this report; USAEC, 1973). The relevant data are listed in Table 6.

Again, the $1998{ }^{137}$ Cs inventory was decay corrected back to 1954 with a subsequent doubling to account for possible environmental losses. About $63.9 \%$ of the total yield at Enewetak occurred during or after 1954, with $50.6 \%$ occurring in 1958 . About $36 \%$ occurred before 1954 and was mostly due to the $10.9 \mathrm{mt}$ Mike test. Consequently, decay-correcting the data to 1954 again provides a conservative estimate of the early inventory from testing. Similar ratios as for Bikini were made to account for the inventory deposited on the reef and lagoon. The total estimated ${ }^{137} \mathrm{Cs}$ inventory in 1954 is estimated to be $3.7 \times 10^{14} \mathrm{~Bq}$.

The total estimated ${ }^{137} \mathrm{Cs}$ inventory in 1954 at the two atolls is $1.0 \times 10^{15} \mathrm{~Bq}$.

Table 6. The estimation of ${ }^{137}$ Cs inventory at Enewetak Atoll in 1954.

\begin{tabular}{|c|c|c|c|c|}
\hline \multicolumn{2}{|c|}{ Location } & $\begin{array}{l}\text { Area } \\
\mathrm{km}^{2}\end{array}$ & $\begin{array}{l}\mathrm{Bq} \mathrm{km}-2 \\
\text { to } 60 \mathrm{~cm}^{\mathrm{a}}\end{array}$ & $\begin{array}{c}\text { Inventory } \\
\mathrm{Bq}\end{array}$ \\
\hline \multicolumn{2}{|c|}{ Southern Islands } & 3.5 & $0.026 \times 10^{11}$ & $0.091 \times 10^{11^{\mathrm{a}}}$ \\
\hline \multicolumn{2}{|c|}{ Northeast Islands } & 1.7 & $0.3 \times 10^{11}$ & $0.50 \times 10^{11^{\mathrm{a}}}$ \\
\hline \multicolumn{2}{|c|}{ Northern Islands } & 1.7 & $2.8 \times 10^{11}$ & $4.8 \times 10^{11^{\mathrm{a}}}$ \\
\hline & Total & 6.9 & & $5.4 \times 10^{11^{\mathrm{a}}}$ \\
\hline \multicolumn{4}{|c|}{ Decay correct to 1954} & $1.4 \times 10^{12^{b}}$ \\
\hline \multicolumn{4}{|c|}{ Correct for environmental loss } & $2.7 \times 10^{12^{b}}$ \\
\hline Reef & \multicolumn{3}{|c|}{63} & $2.5 \times 10^{13^{b}}$ \\
\hline \multirow[t]{2}{*}{ Lagoon } & \multicolumn{3}{|c|}{930} & $3.7 \times 10^{14^{b}}$ \\
\hline & \multicolumn{3}{|c|}{ Total ${ }^{137}$ Cs inventory, 1954} & $3.7 \times 10^{14^{b}}$ \\
\hline
\end{tabular}

a As of 1998

b As of 1954 (the midyear of the major test series at Enewetak). 
The Fraction of the ${ }^{137}$ Cs Fission Product Inventory Produced During Testing That Remained at the Atolls

The total ${ }^{137} \mathrm{Cs}$ production at the atolls was $3.45 \times 10^{17} \mathrm{~Bq}$. The estimated ${ }^{137} \mathrm{Cs}$ inventory at the atolls from close in fallout in 1954 was $1 \times 10^{15} \mathrm{~Bq}$. Thus, the estimated fraction of the ${ }^{137} \mathrm{Cs}$ inventory produced as a result of the test program that was deposited at Bikini and Enewetak in 1954 is

$$
\frac{1.0 \times 10^{15} \mathrm{~Bq}}{3.45 \times 10^{17} \mathrm{~Bq}}=0.0029 \text {. }
$$

For the calculations to follow, this fraction was increased by $50 \%$ to $0.0042(0.42 \%)$ to account for uncertainty in the distribution of the more refractory elements.
The ${ }^{90}$ Sr inventory measured to $30-\mathrm{cm}$ depth in Enewetak lagoon and decay corrected to 1998 was 37 TBq (Robison and Noshkin, 1999). Adjusting this value to account for the land and reef area provides an estimate of the total ${ }^{90} \mathrm{Sr}$ inventory at the atoll of $39.8 \mathrm{TBq}$. Decay-correcting this value to 1954 leads to an estimated inventory of $91 \mathrm{TBq}$ or $9.1 \times 10^{13} \mathrm{~Bq}$. The ${ }^{90} \mathrm{Sr}$ inventory produced during the nuclear test program is $78 \mathrm{PBq}$ or $7.8 \times 10^{16} \mathrm{~Bq}$. The fraction of the produced inventory that remained at the atoll in 1954 based on this analysis is $9.1 \times 10^{13} / 7.8 \times 10^{16}=0.0012$ or $0.12 \%$, which is lower by about a factor of four than the inventory fraction of $0.42 \%$ we are using based on the ${ }^{137} \mathrm{Cs}$ analysis. In this maximizing assumption, it is assumed that no loss of ${ }^{90} \mathrm{Sr}$ occurred by environmental processes from 1954 to 1998, which, of course, is an oversimplification of the real situation.

\section{The Concentration and Inventory of the Elements Listed in Table 1 at the Atolls Today}

\section{Po and ${ }^{228} \mathrm{Th}$}

The amount of ${ }^{210} \mathrm{Po}$ and ${ }^{228} \mathrm{Th}$ included in the nuclear weapons tests was respectively, $1.09 \mathrm{~g}$ and $0.0023 \mathrm{~g}$. The radiological half-life for each of these radionuclides is 138.4 days for ${ }^{210} \mathrm{Po}$ [decays to stable lead $(\mathrm{Pb})$ ], and 1.913 years for ${ }^{228} \mathrm{Th}$ (decays through daughter products leading to stable $\mathrm{Pb}$ ). Consequently, the ${ }^{210}$ Po was gone within about two years, and the ${ }^{228} \mathrm{Th}$ within about 10 years after the final test series. Moreover, the amounts remaining at the atolls after detonation would be extremely small after dispersion.

In summary, on the basis of the information provided, we have concluded that the concentration of ${ }^{210} \mathrm{Po}$ and ${ }^{228} \mathrm{Th}$ in the environment pose no adverse health effects to humans.

\section{${ }^{241} \mathrm{Am}$ and ${ }^{242} \mathrm{Cm}$}

The amount of ${ }^{241} \mathrm{Am}$ (half-life $432.7 \mathrm{y}$ ) introduced as the radionuclide itself (that is, not generated by decay of ${ }^{241} \mathrm{Pu}$ ) was only 0.29 grams. As with the previous two radionuclides only a small amount of this material remained at the atolls subsequent to the detonation of the nuclear devices. Most of the ${ }^{241} \mathrm{Am}$ at the atolls today was produced by the decay of ${ }^{241} \mathrm{Pu}$ produced in the nuclear tests.

We have measured ${ }^{241} \mathrm{Am}$ routinely in the Bikini and Enewetak Atolls' environment. The dose from ${ }^{241} \mathrm{Am}$ is very small and has been evaluated many times; its contribution is less than $0.5 \%$ of the estimated 50 -y integral dose from all pathways at Bikini and Enewetak. (Robison et al., 1982, 1987, 1994, 1997, 1999; Shinn et al., 1997; Robison and Noshkin, 1999).

Curium-242 has a half-life of 162.94 days. All of the isotope used as a tracer would have decayed to ${ }^{238} \mathrm{Pu}$ by the year 2000 .

Plutonium-238 (half-life $87.7 \mathrm{y}$ ) in turn decays to Uranium-234 $\left({ }^{234} \mathrm{U}\right)$, which has a half-life of $2.454 \times 10^{5} \mathrm{y}$. However, the amounts of ${ }^{238} \mathrm{Pu}$ present in the atolls' environment that resulted directly from testing greatly exceeds the amount generated from decay of the ${ }^{242} \mathrm{Cm}$ tracer. For example, the $1.8 \mathrm{~g}$ of ${ }^{242} \mathrm{Cm}$ decays to $0.90 \mathrm{TBq}$ of ${ }^{238} \mathrm{Pu}$ in $4.5 \mathrm{y}$. The inventory of ${ }^{238} \mathrm{Pu}$ at Bikini and Enewetak Atolls from the nuclear testing is 13 TBq (Robison and Noshkin, 1999; Noshkin et al., 1998). The present day dose from ${ }^{238} \mathrm{Pu}$ at the atolls is an insignificant part of the total 
estimated dose at the atolls (Robison and Noshkin, 1999).

There were only 1.8 grams of ${ }^{242} \mathrm{Cm}$ associated with the tests. The amount remaining at the atolls would be no more than about $0.007 \mathrm{~g}$. This amount of material, and the associated daughter products, would be undetectable today if spread over an area the size of Bikini or Eneu Islands. Moreover, ${ }^{238} \mathrm{Pu}$ levels have been evaluated in marine food products at the atolls (Robison and Noshkin, 1999; Noshkin et al., 1998) and shown to contribute little to the estimated dose for people living at the atolls.

In summary, based on the information provided, we conclude that the environmental concentration of ${ }^{241} \mathrm{Am}$ and ${ }^{242} \mathrm{Cm}$ or daughter products resulting from these tracers pose no adverse health effects to people living on the atolls.

\section{Stable S, As, Y, Rh, In, Ta, W, Au, and T1}

The S, As, Y, Rh, In, Ta, W, Au, and Tl elements were used primarily to determine the neutron energy and flux generated in the nuclear explosion. Hence, these elements were fabricated with the large- yield, multistage devices. Small particles of different energy interacted with a fraction of these materials to yield radioactive isotopes that were used for diagnostic purposes. These radioisotopes had half-lives the order of days, weeks or months, and have since disappeared as a result of radiological decay. Radiochemists at LLNL (Moody, Lougheed; private communication) estimate that about 10 to $20 \%$ of the total atoms for each of these elements were activated. However, to be conservative, we will use the entire amount of the material listed in Table 1 knowing it as an overestimate. Moreover, and more important, is the fact that the fraction of these elements remaining at the atolls should be close in value to the fraction of the ${ }^{137} \mathrm{Cs}$ inventory which remained at the atolls. Therefore, we should expect there to be no more than 0.0042 of the original quantity remaining after the detonations. Thus, the maximum amount of the distributed materials within Bikini and Enewetak Atolls is given in column 3 of Table 7.

If these quantities are distributed over one half the area of both Bikini and Enewetak Atolls (a conservative assumption in that the fission products are found at various levels over the entire atoll), the resulting concentration of the elements in the soil are in the picogram range to the femtogram range (see glossary for interpretation of the units), assuming a mixing depth of $20 \mathrm{~cm}$ (fission products are observed at greater depth). The results are shown in Table 8 and compared with the natural concentration of these elements in soils of carbonate origin.

First, the comparison shows that the concentrations of the elements originating from the nuclear tests would be near or below the detection limits in soils using any number of analytical methods. Second, these concentrations are lower by factors ranging from 50 thousand to 10 billion than the natural concentration of these elements in carbonate soil of marine origin (Table 8). Consequently, we conclude that the environmental concentration of these elements pose no adverse health effects to people living on or resettling the atolls. In fact, except for ${ }^{210} \mathrm{Po}$, there was far more of each of the elements listed in Table 1 in the coral, coral sand, and coral sediment that was dislodged and redistributed by the Mike and Bravo tests (forming the large craters) than was involved in the tests.

\section{${ }^{230} \mathrm{Th},{ }^{232} \mathrm{Th}$, and ${ }^{233} \mathrm{U}$}

The listed quantities used during the nuclear test program are about $1.5 \mathrm{~kg}$ of ${ }^{230} \mathrm{Th}$, $1.1 \mathrm{~kg}$ of ${ }^{233} \mathrm{U}$, and $1,080 \mathrm{~kg}$ of ${ }^{232} \mathrm{Th}$. The quantities remaining for distribution at the atolls after detonation are $0.0063 \mathrm{~kg}, 0.0046 \mathrm{~kg}$, and $4.6 \mathrm{~kg}$, respectively (Table 7). This calculation is based on the distribution factor of 0.0042 . These quantities of materials when distributed over one half the area of both Bikini and Enewetak Atolls leads to concentrations in the soil for ${ }^{230} \mathrm{Th}$ and ${ }^{233} \mathrm{U}$ in the range of attograms per gram of soil. These concentrations are extremely low and of no consequence to human health. 
Table 7. The quantity of materials in Table 1 that was available for local distribution at the atolls subsequent to detonation.

\begin{tabular}{lcc}
\hline & $\begin{array}{c}\text { Amounts } \\
\text { for } \\
\text { in tests } \\
\mathrm{kg}\end{array}$ & $\begin{array}{c}\text { distribution } \\
\text { at atolls } \\
\mathrm{kg}\end{array}$ \\
\hline Sulfur & 727 & 3.1 \\
Arsenic & 0.0757 & 0.00032 \\
Yttrium & 0.236 & 0.0010 \\
Tantalum & 0.088 & 0.00037 \\
Gold & 0.50 & 0.0021 \\
Rhodium & 0.2 & 0.00084 \\
Indium & 2.66 & 0.011 \\
Tungsten & 3.1 & 0.013 \\
Thallium & 155 & 0.65 \\
230 Th $\left(7.7 \times 10^{4} \mathrm{y}\right)$ & 1.5 & 0.0063 \\
$232 \mathrm{Th}\left(1.4 \times 10^{10} \mathrm{y}\right)$ & 1100 & 4.6 \\
$233 \mathrm{U}\left(1.59 \times 10^{5} \mathrm{y}\right)$ & 1.1 & 0.0046 \\
$238 \mathrm{U}\left(4.468 \times 10^{9} \mathrm{y}\right)$ & 66,980 & 281 \\
\hline
\end{tabular}

Comparing the test-related inventory of both the ${ }^{230} \mathrm{Th}$ and ${ }^{232} \mathrm{Th}$ radionuclides with naturally occurring inventories in the lagoon gives us another perspective. Table 9 lists these results. The test-related inventory of $0.0036 \mathrm{~kg}$ for ${ }^{230} \mathrm{Th}$ and $2.8 \mathrm{~kg}$ for ${ }^{232} \mathrm{Th}$ are a small fraction of the naturally occurring amounts of $281 \mathrm{~kg}$ for ${ }^{230} \mathrm{Th}$ and $250,000 \mathrm{~kg}$ for ${ }^{232} \mathrm{Th}$. Based on the information available, we conclude that there are no health-related concerns from the amount of these materials associated with the test program at the atolls.

\section{U}

By far the largest quantity of test-related material listed in Table 1 is the $66,980 \mathrm{~kg}$ of ${ }^{238} \mathrm{U}$. About $99.3 \%$ of naturally occurring $U$ is ${ }^{238} U$. Of the $66,980 \mathrm{~kg}$ associated with the tests, about 281 $\mathrm{kg}(66,980 \mathrm{~kg} * 0.0042)$ would be expected to be available for local distribution at the atolls after detonation (Table 7), with most of the ${ }^{238} \mathrm{U}$ being distributed over the open oceans and worldwide land masses. This is a maximizing method of calculation for the available ${ }^{238} \mathrm{U}$ because a significant fraction of the ${ }^{238} \mathrm{U}$ would be fissioned in the detonation, and the amount remaining at the atolls would be less as a result. Distribution of the $281 \mathrm{~kg}$ of ${ }^{238} \mathrm{U}$ over one half the area of both Bikini and Enewetak Atolls leads to an estimated concentration (to a depth of $20 \mathrm{~cm}$ ) of about $0.0014 \mu \mathrm{g}^{238} \mathrm{U}$ per $\mathrm{g}$ of soil (Table 8).

\section{The Natural Uranium Concentration in Marine Corals}

Several investigators have measured the naturally occurring concentration of $U$ in marine corals from around the world. A detailed study of the uranium series radionuclides was conducted on coral samples from Enewetak Atoll whose ages predated the nuclear testing program at the atolls (Thurber et al., 1965). The mean concentration plus or minus one standard error (SE) of ${ }^{238} \mathrm{U}$ in 36 coral samples was $2.9 \pm 0.094 \mu \mathrm{g}{ }^{238} \mathrm{U}$ per $\mathrm{g}$ of coral. One of the samples was a live coral with a concentration of $3.3 \mu \mathrm{g} \mathrm{U}$ per g of coral. Barnes et al. (1956) also reported the $\mathrm{U}$ concentration in Enewetak corals at $3.9 \pm 0.14 \mu \mathrm{g} \mathrm{U}$ per $\mathrm{g}$ of coral. Moreover, coral samples from the Florida Keys were dated using the uranium-series isotopes, and the ${ }^{238} \mathrm{U}$ 
Table 8. The concentration of the test-related elements after detonation compared with the respective naturally occurring concentrations in coral soils.

Half the area of both Bikini and Enewetak Atolls

\begin{tabular}{lclcc}
\cline { 2 - 5 } Element & $\begin{array}{c}\text { Quantity } \\
\text { in tests } \\
\mathrm{kg}\end{array}$ & $\begin{array}{c}\text { Distributed } \\
\text { concentration } \\
\mathrm{ng} \mathrm{g}^{-1}\end{array}$ & $\begin{array}{c}\text { Naturally } \\
\text { in soil } \\
\text { ng g }^{-1}\end{array}$ & $\begin{array}{c}\text { Ratio of } \\
\text { natural to } \\
\text { test-related } \\
\text { concentration }\end{array}$ \\
\hline Sulfur & 727 & 0.015 & $150,000^{\mathrm{b}}$ & $1.0 \times 10^{7}$ \\
Arsenic & 0.0757 & 0.0000015 & 1,000 & $6.5 \times 10^{8}$ \\
Yttrium & 0.236 & 0.0000048 & $42,000^{\mathrm{b}}$ & $8.7 \times 10^{9}$ \\
Tantalum & 0.088 & 0.0000018 & $10^{\mathrm{b}}$ & $5.6 \times 10^{6}$ \\
Gold & 0.5 & 0.0000102 & - & - \\
Rhodium & 0.2 & 0.0000041 & - & - \\
Indium & 2.66 & 0.000054 & $20^{\mathrm{b}}$ & $3.7 \times 10^{5}$ \\
Tungsten & 3.1 & 0.000063 & $110^{\mathrm{b}}$ & $1.7 \times 10^{6}$ \\
Thallium & 155 & 0.0032 & $160^{\mathrm{b}}$ & $5.1 \times 10^{4}$ \\
$230 \mathrm{Th}\left(7.7 \times 10^{4} \mathrm{y}\right)$ & 1.5 & 0.000030 & $0.2^{\mathrm{c}}$ & $6.6 \times 10^{3}$ \\
$232 \mathrm{Th}\left(1.4 \times 10^{10} \mathrm{y}\right)$ & 1100 & 0.022 & $1,000^{\mathrm{c}}$ & $4.5 \times 10^{4}$ \\
$233 \mathrm{U}\left(1.59 \times 10^{5} \mathrm{y}\right)$ & 1.1 & 0.000022 & - & $1.5 \times 10^{3}$ \\
$238 \mathrm{U}\left(4.468 \times 10^{9} \mathrm{y}\right)$ & 66,980 & 1.4 & $2,000^{\mathrm{d}}$ & \\
\hline
\end{tabular}

a To 20-cm depth, a distribution factor of 0.0042 .

b IAEA(1985).

c Park et al. (1983).

d See Tables 11-15.

Table 9. The naturally occurring amount of ${ }^{230} \mathrm{Th}$ and ${ }^{232} \mathrm{Th}$ in the lagoons at Bikini and Enewetak Atolls compared with the test-related quantities.

\begin{tabular}{|c|c|c|}
\hline & \multicolumn{2}{|c|}{$\begin{array}{l}\text { Bikini plus Enewetak lagoon } \\
\text { inventory }\end{array}$} \\
\hline & $\begin{array}{c}{ }^{230} \mathrm{Th}^{\mathrm{a}} \\
\mathrm{kg}\end{array}$ & $\begin{array}{l}{ }^{232} \mathrm{Th}^{\mathrm{b}} \\
\mathrm{kg}\end{array}$ \\
\hline Naturally in lagoon sediment & 281 & $2.5 \times 10^{5}$ \\
\hline Naturally in lagoon water & 0.029 & 10 to 150 \\
\hline Naturally occurring total & 281 & 250,000 \\
\hline Test related after detonation & 0.0036 & 2.8 \\
\hline
\end{tabular}

a Park et al. (1983).

b IAEA (1985). 
concentration for fifteen samples was $2.7 \pm 0.065$ $\mu \mathrm{g}{ }^{238} \mathrm{U}$ per $\mathrm{g}$ (Broecker and Thurber, 1965). The $\mathrm{U}$ concentration in all of these corals from around the world is the same as that found in the Marshall Island corals.

Tatsumoto and Goldberg (1959) also analyzed corals from the Florida Keys and found a $\mathrm{U}$ concentration of $2.9 \pm 0.35 \mu \mathrm{g}$ per $\mathrm{g}$ of coral. Veeh and Turekian (1968) analyzed coral samples from Hawaii, Samoa, Tahiti, and Tuamotu and found $U$ concentrations of $2.5 \pm 0.20,2.3 \pm 0.22,2.1 \pm 0.11$, and $1.8 \pm 0.12 \mu \mathrm{g}$ $\mathrm{U}$ per $\mathrm{g}$ of coral, respectively. All of these data are listed in Table 10. The U concentration in all of these corals from around the world is the same as that found in the Marshall Island corals.

Thus, the naturally occurring concentration of $U$ in coral (i.e., the material from which the islands soils are derived) is about $3 \mu \mathrm{g}$ per $\mathrm{g}$ of coral (range from about 2 to $5 \mu \mathrm{g} \mathrm{g}^{-1}$ ), which is a factor of 1000 to 2500 greater than the concentrations estimated for the test-related deposition of ${ }^{238} \mathrm{U}$ at the atolls (Table 8). Consequently, the test-related ${ }^{238} \mathrm{U}$ at the atolls would be immeasurable relative to the mean value and range of naturally occurring concentrations of $U$ in coral soils.
It is pointed out by Thurber et al. (1965) that recrystallization occurs in corals in open systems, such as island soils, that changes some of the natural aragonite coral matrix to a calcite matrix. The recrystallization process often leads to a reduction in the uranium concentration. The concentrations of ${ }^{238} \mathrm{U}$ in coral soils, representing corals in an open system, are listed in Tables 11, 12, 13, and 14. These data are from atolls/islands in the northern, mid, and southern Marshall Islands and two islands from the Carolina Islands. They are primarily from two different research groups, LLNL and RMI. The LLNL uranium concentrations in coral soil range from 1.4 to $3.6 \mu \mathrm{g}{ }^{238} \mathrm{U}$ per $\mathrm{g}$ with a mean \pm 1 SE of $1.9 \pm 0.083$; the RMI data range from 1.2 to $3.6^{238} \mathrm{U}$ per $\mathrm{g}$ of coral soil with a mean $\pm 1 \mathrm{SE}$ of $2.1 \pm 0.081$. The mean values for the closedsystem parent corals listed in Table 10, and coral soils from both groups discussed above are statistically different $(\mathrm{LLNL}-\mathrm{T}=3.77, \mathrm{df}=37$, $\left.\mathrm{p}=5.5 \times 10^{-4} ; \mathrm{RMI}-\mathrm{T}=2.53, \mathrm{df}=39, \mathrm{p}=0.015\right)$. Albeit, based on the small set of samples for parent corals, there is evidence that the $\mathrm{U}$ concentrations in open-system coral soils differ from that of closed-system parent corals.

Table 10. The concentration of ${ }^{238} \mathrm{U}$ in corals from global locations.

\begin{tabular}{|c|c|c|c|}
\hline Location & $\begin{array}{c}\text { Number } \\
\text { of } \\
\text { samples }\end{array}$ & $\begin{array}{c}\text { Mean } \pm 1 \text { SE } \\
238 \mathrm{U} \text { or } \mathrm{U} \\
\mu \mathrm{g} \mathrm{g}^{-1}\end{array}$ & Source \\
\hline Enewetak & 36 & $2.9 \pm 0.090$ & Thurber et al. (1965) \\
\hline Florida Keys & 15 & $2.7 \pm 0.065$ & Broeker and Thurber (1965) \\
\hline Hawaii ${ }^{\mathrm{a}}$ & 6 & $2.5 \pm 0.20$ & Veeh and Turekian (1968) \\
\hline Samoab & 5 & $2.3 \pm 0.22$ & Veeh and Turekian (1968) \\
\hline Tahitib & 5 & $2.1 \pm 0.11$ & Veeh and Turekian (1968) \\
\hline Tuamotu $^{\mathrm{b}}$ & 8 & $1.8 \pm 0.12$ & Veeh and Turekian (1968) \\
\hline Enewetak & 18 & $3.9 \pm 0.14$ & Barnes et al. (1956) \\
\hline Florida Keys ${ }^{\mathrm{C}}$ & 2 & $2.9 \pm 0.35$ & Tatsumoto andGoldberg (1959) \\
\hline All samples & 95 & $2.9 \pm 0.094^{\mathrm{d}}$ & \\
\hline All locations & 8 & $2.6 \pm 0.26^{\mathrm{d}}$ & \\
\hline
\end{tabular}

a Three samples each of two genus of corals.

b Three samples of one genus of coral, and two samples of another genus of coral.

c Two genus of corals.

d SE values for island-specific means were calculated to reflect sampling as well as measurement error; $\mathrm{SE}$ value for the (unweighted) all-island mean $(n=8)$ reflects only inter-island variability in mean ${ }^{238} \mathrm{U}$ concentration. 
Table 11. The mean concentration of ${ }^{238} \mathrm{U}$ in coral soil from Majuro, Kwajalein, Wotje, Ponape, and Truk.

\begin{tabular}{|c|c|c|c|}
\hline Location & $\begin{array}{c}\text { Number } \\
\text { of } \\
\text { samples }\end{array}$ & $\begin{array}{c}\text { Mean } \pm 1 \mathrm{SE}^{\mathrm{a}} \\
238 \mathrm{U} \\
\mu \mathrm{g} \mathrm{g} \mathrm{g}^{-1}\end{array}$ & Source \\
\hline Majuro $^{b}$ & 8 & $2.2 \pm 0.36$ & Nelson $^{f}(1979 a)$ \\
\hline Majurob & 5 & $1.7 \pm 0.38$ & LLNLg, this report \\
\hline Majuro $^{C}$ & 40 & $1.7 \pm 0.10$ & LLNL $^{\mathrm{f}}$, this report \\
\hline Wotje ${ }^{\mathrm{d}}$ & 14 & $2.1 \pm 0.21$ & Nelson $^{f}(1979 b)$ \\
\hline Kwajaleine & 57 & $1.9 \pm 0.087$ & LLNLg, this report \\
\hline Ponape & 12 & $2.8 \pm 0.32$ & Nelsonf (1979a) \\
\hline Truk & 13 & $3.6 \pm 0.32$ & Nelson $^{f}$ (1979a) \\
\hline All samples & 149 & $2.1 \pm 0.077$ & \\
\hline All islands & 7 & $2.3 \pm 0.26$ & \\
\hline
\end{tabular}

a SE values for island-specific means were calculated to reflect sampling as well as measurement error; $S E$ value for the (unweighted) all-island mean $(n=7)$ reflects only inter-island variability in mean ${ }^{238} \mathrm{U}$ concentration. By analysis of variance, the island-specific concentrations differ significantly from one another $(\mathrm{F}=183.4, \mathrm{df}=6$ and $142, \mathrm{p} \approx 0)$. Consequently, ${ }^{238} \mathrm{U}$ concentrations in control coral soil were compared to those soils in the northern Marshall Islands using island-specific means without regard to sample number.

$\mathrm{b}$ Majuro to Laura.

c Majuro, Enemanet, and Eneko Islands.

$\mathrm{d}$ Wormej and Wotje Islands.

e Gagan, Gellinam, Roi Namur, and Illeginni Islands.

f Data generated by gamma spectroscopy.

$\mathrm{g}$ Data generated by ICP mass spectrometry.

\section{The Uranium Concentration in Soils and Sediments in the Marshall Islands}

The conclusion that the test-related ${ }^{238} \mathrm{U}$ has not increased the $U$ concentration at the atolls to levels that are measurable can be evaluated with data from several sources for atolls in the northern Marshall Islands that were contaminated with fallout. Samples collected from 13 islands at Bikini Atoll in 1978 have a weighted mean and SE of $2.1 \pm 0.067 \mu \mathrm{g}^{238} \mathrm{U}$ per $\mathrm{g}$ of soil (Table 12). The comparable data for other atoll locations range from

$1.4 \pm 0.084$ to $2.6 \pm 0.50 \mu \mathrm{g}{ }^{238} \mathrm{U}$ per $\mathrm{g}$ of soil. The results for lagoon sediment samples are: Bikini lagoon, $2.8 \pm 0.10$; Rongelap lagoon, $2.7 \pm 0.14$; and Enewetak lagoon, $4.0 \pm 0.16$. Also, a bulk soil sample from Eneu Island was homogenized and sent to the International Atomic Energy Agency (IAEA) in Monaco. The sample was distributed to 68 international laboratories. The reference value recommended by the IAEA from this exercise is $1.63 \mu \mathrm{g}$ of ${ }^{238} \mathrm{U}$ per $\mathrm{g}$ of soil with a range from $0.9 \mu \mathrm{g} \mathrm{g}^{-1}$ to $3 \mu \mathrm{g} \mathrm{g}^{-1}$.

The ${ }^{238} \mathrm{U}$ concentrations for these locations in the northern Marshall Islands (Table 12) that were exposed to the highest deposition of radionuclides are not statistically different $(\mathrm{T}=1.7, \mathrm{df}=17, \mathrm{p}=0.10)$ than those of the control atolls listed in Table 11.

A similar comparison can be made from ${ }^{238} \mathrm{U}$ data obtained at Enewetak Atoll (Table 13). The mean concentration of ${ }^{238} \mathrm{U}$ and its SE for the four southern islands at Enewetak Atoll is $1.7 \pm 0.12 \mu \mathrm{g}$ per $\mathrm{g}$ of soil which is the same as that observed at the other atolls (Tables 11 and 12). These southern islands received regional fallout deposition that is, at most, only marginally above the worldwide fallout deposition for the $0-10^{\circ}$ latitude band. Thus, these values are essentially the naturally occurring U concentrations in coral soils. 
Table 12. The concentration of ${ }^{238} \mathrm{U}$ in soil and lagoon sediments at the northern Marshall Islands.

\begin{tabular}{|c|c|c|c|c|}
\hline Location & $\begin{array}{l}\text { Number } \\
\text { of } \\
\text { samples }\end{array}$ & $\begin{array}{c}\text { Mean } \pm 1 \mathrm{SE}^{\mathrm{a}} \\
238 \mathrm{U} \\
\mu \mathrm{g} \mathrm{g}^{-1}\end{array}$ & Source & Method \\
\hline Bikini Atoll ${ }^{b}$ & 100 & $2.1 \pm 0.067$ & LLNL, this report & gamma spec. \\
\hline Rongelap Island & 15 & $1.7 \pm 0.15$ & ${ }_{N L}$, this report & \\
\hline Rongelap northern island & 50 & $1.4 \pm 0.084$ & LLNL, this report & gamr \\
\hline Rongelap southern island & 176 & $1.7 \pm 0.050$ & LLNL, this report & gamn \\
\hline Mejit Island & 43 & $1.6 \pm 0.084$ & LLNL, this report & gamn \\
\hline Ailuk Atollc & 16 & $2.2 \pm 0.25$ & Nelson, (1979b) & gamm \\
\hline Ailuk Atoll ${ }^{\mathrm{d}}$ & 99 & $1.9 \pm 0.069$ & LLNL, this report & gamma spec. \\
\hline Utirik Atolle & 5 & $2.6 \pm 0.50$ & b) & gamm \\
\hline Utirik Atolle & 548 & $1.6 \pm 0.037$ & LLNL, this report & gamma spec. \\
\hline Likiep Atollf & 68 & $2.3 \pm 0.19$ & LLNL, this report & gamma spec. \\
\hline Enewetak Atollg & 183 & $1.9 \pm 0.061$ & & gamma spec. \\
\hline Rongerik Atoll ${ }^{\mathrm{h}}$ & 25 & $1.5 \pm 0.12$ & LLNL, this report & \\
\hline $\begin{array}{l}\text { All samples } \\
\text { All atolls/islands }\end{array}$ & $\begin{array}{r}1328 \\
12\end{array}$ & $\begin{array}{l}1.8 \pm 0.024 \\
1.9 \pm 0.10\end{array}$ & & \\
\hline Bikini lagoon $^{\mathrm{i}}$ & 89 & $2.8 \pm 0.10$ & $\begin{array}{l}\text { Marshall and Schell (1974) } \\
\text { Noshkin, this report } \\
\text { Noshkin, this report }\end{array}$ & $\begin{array}{l}\text { alpha spec. } \\
\text { mass spec. } \\
\text { gamma spec. }\end{array}$ \\
\hline Rongelap lagoon & 21 & $2.7 \pm 0.14$ & Noshkin, this report & gamma spec. \\
\hline Enewetak lagoon & $\begin{array}{l}\quad 76 \\
\text { Reference } \\
\text { Value Range }\end{array}$ & $4.0 \pm 0.16$ & Noshkin, this report & gamma spec. \\
\hline Eneu Island & 1 & 0.9 to 3 & IAEA (1998) & \\
\hline \multicolumn{5}{|c|}{$\begin{array}{l}\text { a SE values for island-specific means were calculated to reflect sampling as well as measurement error; } \\
\text { SE value for the (unweighted) all-atoll/island mean ( } \mathrm{n}=12 \text { ) reflects only inter-island variability in mean } \\
238 \mathrm{U} \text { concentration. By analysis of variance, the island-specific concentrations differ significantly from one } \\
\text { another ( } \mathrm{F}=934.4, \mathrm{df}=11 \text { and } 1316, \mathrm{p} \approx 0 \text { ). Consequently, }{ }^{238} \mathrm{U} \text { concentrations in the northern Marshall } \\
\text { Islands soil were compared to those control atolls listed in Table } 11 \text { using island-specific means without } \\
\text { regard to sample number. } \\
\text { b Nam (13), Iroij (4), Odrik (1), Lomilik (2), Bikini (7), Aerokojlo (36), Lele (5), Eneman (3), Enedrik (16), } \\
\text { Lukoj (9), and Jelete (4). } \\
\text { c Ailuk and Bigen Islands. } \\
\text { d Kapen, Enijabro, Enejelar, Bigen, and Aliet Islands. } \\
\text { e Aon and Eerukku Islands, for Nelson; Utirik, Aon, Bigrak, Eerukku Islands for LLNL. } \\
\text { f Likiep, Agohy, and Etoile Islands. } \\
\text { g Enjebi Island. } \\
\text { h Jedibberbid,Latoback, Rongerik, Eniwetak, and Bock Islands } \\
\text { i No of samples; Marshall and Schell-11; Noshkin-20; Noshkin-58 }\end{array}$} \\
\hline
\end{tabular}


Table 13. The concentration of ${ }^{238} \mathrm{U}$ in soil at Enewetak Atoll.

\begin{tabular}{lrc}
\hline \multicolumn{1}{c}{ Location } & Number of samples & Mean ${ }^{238} \mathrm{U} \pm 1 \mathrm{SE}, \mu \mathrm{g} \mathrm{g}^{-1}$ \\
\hline Southern Islands ${ }^{\mathrm{a}}$ & & \\
$\quad$ Anniji & 29 & $1.4 \pm 0.11$ \\
$\quad$ Japtan & 131 & $2.0 \pm 0.10$ \\
$\quad$ Medren & 304 & $1.7 \pm 0.079$ \\
$\quad$ Enewetak & 422 & $1.7 \pm 0.086$ \\
$\quad$ & & \\
$\quad$ All samples & 886 & $1.8 \pm 0.024$ \\
$\quad$ All islands & 4 & $1.7 \pm 0.12$ \\
& & \\
Northern and Eastern Islands ${ }^{\mathrm{b}}$ & 15 & $1.8 \pm 0.15$ \\
Aje & 45 & $1.4 \pm 0.083$ \\
Lujor & 25 & $1.8 \pm 0.19$ \\
Aomen & 46 & $1.5 \pm 0.12$ \\
Bijire & 55 & $1.6 \pm 0.11$ \\
Lojwa & 50 & $1.7 \pm 0.10$ \\
Alembel & 70 & $1.5 \pm 0.080$ \\
Runit & 183 & $1.9 \pm 0.061$ \\
Enjebi & & \\
All samples & 489 & $1.7 \pm 0.034$ \\
All islands & 8 & $1.7 \pm 0.063$ \\
\hline
\end{tabular}

a SE values for island-specific means were calculated to reflect sampling as well as measurement error; $\mathrm{SE}$ value for the (unweighted) all-island mean $(\mathrm{n}=4)$ reflects only inter-island variability in mean ${ }^{238} \mathrm{U}$ concentration. By analysis of variance, the island-specific concentrations differ significantly from one another $(\mathrm{F}=754.4, \mathrm{df}=3$ and $882, \mathrm{p} \approx 0)$. Consequently, ${ }^{238} \mathrm{U}$ concentrations in soil in the southern islands were compared to soil in the northern and eastern islands using island-specific means without regard to sample number.

b SE values for island-specific means were calculated to reflect sampling as well as measurement error; SE value for the (unweighted) all-island mean $(n=8)$ reflects only inter-island variability in mean ${ }^{238} \mathrm{U}$ concentration. By analysis of variance, the island-specific concentrations differ significantly from one another $(\mathrm{F}=274.8, \mathrm{~d} \mathrm{f}=7$ and $481, \mathrm{p} \approx 0)$. Consequently, ${ }^{238} \mathrm{U}$ concentrations in soil in the northern and eastern islands were compared to soil in the southern islands using island-specific means without regard to sample number.

For comparison, the mean ${ }^{238} \mathrm{U}$ concentration and the SE of the mean for the eight northeastern chain of islands, where significant nuclear testing occurred near or on the islands, is $1.7 \pm 0.063 \mu \mathrm{g}{ }^{238} \mathrm{U}$ per $\mathrm{g}$ of soil (Table 13). The mean ${ }^{238} \mathrm{U}$ concentration for the eight northeastern islands does not differ significantly from that of the four southern islands $(\mathrm{T}=0.41, \mathrm{df}=10, \mathrm{p}=0.69)$. For Enjebi Island in the north, where three tests were conducted on the island itself, the mean ${ }^{238} \mathrm{U}$ concentration $( \pm 1 \mathrm{SE})$ is $1.9 \pm 0.061 \mu \mathrm{g}{ }^{238} \mathrm{U}$ per $\mathrm{g}$ soil. Although this mean for Enjebi Island is statistically significantly greater than the corresponding mean $\left(1.6 \pm 0.059 \mu \mathrm{g} \mathrm{g}^{-1}\right)$ for the remaining seven northeastern islands (excluding Enjebi Island), the Enjebi mean does not differ significantly from that measured for the four southern islands at Enewetak Atoll $(\mathrm{T}=1.63$, $\mathrm{df}=3, \mathrm{p}=0.20)$ at which $\mathrm{U}$ levels in soil are, as noted above, essentially the naturally occurring U concentrations in coral soils. Consequently, there is no evidence that any input of $U$ from the test program is presently detectable at Enewetak Atoll.

The most extensive data base on the ${ }^{238} \mathrm{U}$ concentration in the Marshall Islands comes from the Republic of the Marshall Islands 
Table 14. The concentration of ${ }^{238} \mathrm{U}$ in soil for atolls in the Marshall Islands. ${ }^{a}$

\begin{tabular}{|c|c|c|c|c|c|}
\hline $\begin{array}{l}\text { Southern } \\
\text { Atolls }\end{array}$ & $\begin{array}{r}\text { Mean } \\
\pm 1 \mathrm{SE}^{\mathrm{b}}\end{array}$ & $\begin{array}{l}\text { Mid } \\
\text { atolls }\end{array}$ & $\begin{array}{c}\text { Mean } \\
\pm 1 \mathrm{SE}^{\mathrm{C}}\end{array}$ & $\begin{array}{l}\text { Northern } \\
\text { atolls }\end{array}$ & $\begin{array}{l}\text { Mean } \\
\pm 1 \mathrm{SE}^{\mathrm{d}}\end{array}$ \\
\hline Ailinglaplap (24) ${ }^{\mathrm{e}}$ & $2.6 \pm 0.20$ & Aur (24) & $2.2 \pm 0.14$ & Ailinginae (54) & $1.6 \pm 0.090$ \\
\hline Arno (24) & $3.3 \pm 0.16$ & Erikub (12) & $1.6 \pm 0.13$ & Ailuk (18) & $1.9 \pm 0.13$ \\
\hline Ebon (18) & $2.2 \pm 0.16$ & Kwajalein (54) & $1.7 \pm 0.093$ & & \\
\hline Jaluit (24) & $2.2 \pm 0.26$ & Lae (18) & $2.5 \pm 0.20$ & Bikini (34) & $1.8 \pm 0.12$ \\
\hline Kili (6) & $3.0 \pm 0.31$ & $\mathrm{Lib}(12)$ & $2.4 \pm 0.10$ & Enewetak (44) & $1.6 \pm 0.071$ \\
\hline Knox (6) & $2.5 \pm 0.31$ & Likiep (36) & $2.2 \pm 0.13$ & Mejit (11) & $1.8 \pm 0.14$ \\
\hline Majuro (72) & $2.5 \pm 0.16$ & Maleolap (24) & $1.5 \pm 0.11$ & Rongelap (106) & $1.7 \pm 0.073$ \\
\hline Namorik (12) & $2.2 \pm 0.41$ & Namu (24) & $2.7 \pm 0.17$ & Rongerik (28) & $1.2 \pm 0.12$ \\
\hline Mili (24) & $2.5 \pm 0.16$ & Ujae (18) & $2.3 \pm 0.17$ & Taongi (18) & $1.8 \pm 0.11$ \\
\hline \multirow[t]{3}{*}{ Jabat (6) } & $2.8 \pm 0.32$ & Ujelang (42) & $2.4 \pm 0.18$ & Taka (24) & $2.0 \pm 0.10$ \\
\hline & & Wotho (18) & $1.9 \pm 0.12$ & Utirik (25) & $1.8 \pm 0.13$ \\
\hline & & Wotje (24) & $1.9 \pm 0.10$ & Jemo (6) & $2.2 \pm 0.3$ \\
\hline All samples (216) & $2.6 \pm 0.078$ & All samples (306) & $2.1 \pm 0.048$ & All samples (368) & $1.7 \pm 0.041$ \\
\hline All atolls (10) & $2.6 \pm 0.12$ & All atolls (12) & $2.1 \pm 0.11$ & All atolls (11) & $1.8 \pm 0.077$ \\
\hline
\end{tabular}

a Data from the RMI Nationwide Radiological Survey.

b SE values for island-specific means were calculated to reflect sampling as well as measurement error; $\mathrm{SE}$ value for the (unweighted) all-atoll/island mean $(\mathrm{n}=10)$ reflects only inter-atoll/island variability in mean ${ }^{238} \mathrm{U}$ concentration. By analysis of variance, the island-specific concentrations differ significantly from one another $(F=52.3, d f=9$ and $206, p \approx 0)$. Consequently, ${ }^{238} \mathrm{U}$ concentrations in the southern atolls soils were compared to those mid and northern atolls using atoll/island-specific means without regard to sample number.

c SE values for island-specific means were calculated to reflect sampling as well as measurement error; $\mathrm{SE}$ value for the (unweighted) all-atoll/island mean $(\mathrm{n}=12)$ reflects only inter-atoll/island variability in mean ${ }^{238} \mathrm{U}$ concentration. By analysis of variance, the island-specific concentrations differ significantly from one another $(\mathrm{F}=178.1, \mathrm{df}=11$ and $294, \mathrm{p} \approx 0)$. Consequently, ${ }^{238} \mathrm{U}$ concentrations in the mid atolls soils were compared to those southern and northern atolls using atoll/island-specific means without regard to sample number

d SE values for island-specific means were calculated to reflect sampling as well as measurement error; $\mathrm{SE}$ value for the (unweighted) all-atoll/island mean $(\mathrm{n}=11)$ reflects only inter-atoll/island variability in mean ${ }^{238} \mathrm{U}$ concentration. By analysis of variance, the island-specific concentrations differ significantly from one another $(\mathrm{F}=113.3, \mathrm{df}=10$ and $357, \mathrm{p} \approx 0)$. Consequently, ${ }^{238} \mathrm{U}$ concentrations in the northern atolls soils were compared to those southern and mid atolls using atoll/island-specific means without regard to sample number

e Number of samples in parentheses.

sponsored radiological survey, directed by Dr. Steve Simon ${ }^{\dagger}$ and conducted from 1989 through 1994. Those data are listed in Table 14 (Simon, 2001, private communication).

These data were generated by gamma spectroscopy of soils collected at the atolls and

\footnotetext{
${ }^{\dagger}$ Dr. Steven L. Simon, National Cancer Institute, 6120 Executive Blvd., MSC7238, Executive Plaza South, Bethesda, MD 20892-7238
}

represent a weighted average of the $63.29 \mathrm{keV}$ line and the $92.8 \mathrm{keV}$ : $92.4 \mathrm{keV}$ lines of ${ }^{234} \mathrm{Th}$, which is the daughter product of ${ }^{238} \mathrm{U}$ used for analytical measurement. The atolls are organized into three categories: southern atolls, mid atolls, and northern atolls. The mean ${ }^{238} \mathrm{U}$ concentration and SE of the mean in $\mu \mathrm{g}{ }^{238} \mathrm{U}$ per $\mathrm{g}$ of soil for the three groups are: southern atolls $2.6 \pm 0.12$, mid atolls $2.1 \pm 0.11$, and northern atolls $1.8 \pm 0.077$. 
The mean concentration of ${ }^{238} \mathrm{U}$ for the southern atolls $(2.6 \pm 0.12)$ is statistically significantly greater than that of the mid atolls $(2.1 \pm 0.11)(\mathrm{T}=2.94, \mathrm{df}=20, \mathrm{p}=0.0081)$. The mean ${ }^{238} \mathrm{U}$ concentration for the mid atolls $(2.1 \pm 0.11)$ is statistically significantly greater than that of the northern atolls $(1.8 \pm 0.077)$ $(\mathrm{T}=2.52, \mathrm{df}=21, \mathrm{p}=0.020)$. Likewise, the mean concentration of ${ }^{238} \mathrm{U}$ for the southern atolls $(2.6 \pm 0.12)$ is statistically significantly greater $\left(\mathrm{T}=6.00, \mathrm{df}=19, \mathrm{p}=8.9 \times 10^{-6}\right)$ than that of the northern atolls $(1.8 \pm 0.077)$ where nuclear testing was actually conducted. In contrast to this south-to-north pattern of decreasing ${ }^{238} \mathrm{U}$ concentrations in soil, it is reasonable to assume that any test-related local ${ }^{238} \mathrm{U}$ fallout in the Marshall Islands would have been greatest in the northernmost islands/atolls where testing occurred, with lesser and/or negligible testrelated local fallout in other islands/atolls to the south. Consequently, we conclude that there is no measurable difference in ${ }^{238} \mathrm{U}$ concentrations within the Marshall Islands that can be explained by the nuclear testing program.

Probably the greatest potential for increased $U$ concentrations at the atolls is in the lagoon sediment because of the many barge shots on the lagoon. Two surveys were conducted at Bikini lagoon: one in 1972 (Marshall and Schell, 1974), and one in 1979 (Noshkin, this report), where sediment samples from across Bikini lagoon were collected and analyzed for ${ }^{238} \mathrm{U}$. One sample from Marshall and Schell was from Bravo Crater where two large thermonuclear devices were detonated. Marshall and Schell (1974) also reported one very high number that was a factor of four greater than the mean value of the data when this data point was not included. The sampling grid reported for both surveys favored the northern half of the atoll and regions near test locations. Marshall and Schell (1974) collected 11 samples that were analyzed by alpha spectrometry. Noshkin (this report) collected 20 samples that were analyzed by mass spectrometry, and 58 samples that were analyzed by gamma spectrometry that were previously unreported. The mean value of ${ }^{238} \mathrm{U}$ for these 89 samples was $2.8 \mu \mathrm{g} \mathrm{g}^{-1}$ with a SE of $0.10 \mu \mathrm{g} \mathrm{g}^{-1}$. Noshkin (this report) also analyzed 20 samples from Rongelap lagoon for many radionuclides. The previously unreported mean value for ${ }^{238} \mathrm{U}$ is $2.7 \pm 0.14 \mu \mathrm{g}{ }^{238} \mathrm{U}$ per $\mathrm{g}$ of sediment (Table 12). He also analyzed 76 sediment samples from Enewetak lagoon. The previously reported mean value for ${ }^{238} \mathrm{U}$ is 4.0 $\mu \mathrm{g} \mathrm{g}^{-1}$ with a SE of $0.16 \mu \mathrm{g} \mathrm{g}^{-1}$. This is similar to the pretest mean concentration of ${ }^{238} \mathrm{U}$ in Enewetak coral of $3.9 \mu \mathrm{g} \mathrm{g}^{-1}$ found by Barnes et al. (1956) (Table 10).

Thus, the mean ${ }^{238} \mathrm{U}$ concentration in coral sediment is the same after the nuclear test program (Table 12) as before the test program (Table 10), indicating no measurable addition of ${ }^{238} \mathrm{U}$.

In summary, data from several different investigators using several different analytical methods all show that there is no statistical difference in ${ }^{238} \mathrm{U}$ concentration in coral samples collected before and after the testing program, or at atolls with the highest contamination of fission products $\left({ }^{137} \mathrm{Cs},{ }^{90} \mathrm{Sr}\right.$, etc.) versus those that received primarily only world wide fallout levels. Thus, we conclude that there are no radiological or toxicological hazards to human health from ${ }^{238} \mathrm{U}$ distributed by the nuclear testing program.

\section{Conclusion}

The estimated concentration in soil at the atolls of the materials associated with the nuclear testing program are today many orders of magnitude below the naturally occurring concentrations of these materials in carbonate coral, and this conclusion applies equally to all atolls in the Marshall Islands. These estimates are based on the fraction of the ${ }^{137} \mathrm{Cs}$ fission product inventory remaining at the atolls in 1954 relative to the total ${ }^{137}$ Cs inventory produced throughout the test program. This fraction was applied to all the materials listed in 
Table 1, and the resulting inventory of materials was distributed over one half of the area of both Bikini and Enewetak Atolls to determine the concentration.

The quantity of ${ }^{238} \mathrm{U}$ listed in Table 1 is greater by factors ranging from 60 to $230,000,000$ than all of the other materials listed. Thus, focusing on ${ }^{238} \mathrm{U}$ puts all of the other materials in perspective. A significant amount of data from several independent investigators using various analytical methods to determine the concentration of ${ }^{238} \mathrm{U}$ in coral, indicates that the ${ }^{238} \mathrm{U}$ concentration in coral is the same at all atolls today, and the same as that observed in corals at the atolls prior to the nuclear testing program. The ${ }^{238} \mathrm{U}$ concentration observed at atolls in the northern Marshall Islands that received the highest levels of fallout is slightly lower than those in the atolls in the south, which received only worldwide fallout levels for the 0 to $15^{\circ}$ latitude band. Based on ${ }^{137} \mathrm{Cs}$ inventories discussed above, these data support the conclusions of the assessment that the concentrations of all of these materials at the atolls is far below the naturally occurring concentration, and cannot be measured at the atolls today.

\section{Summary Statement}

Based on the information provided in Table 1, our analysis leads us to conclude that the environmental concentration of these materials at the atolls is very, very low - they pose no toxicological or radiological risk, and they pose no adverse health affects to people living, or planning to live, on the atolls.

\section{Acknowledgement}

We thank Dr. Ken Moody and Dr. Ron Lougheed of the LLNL Radiochemistry Department for their time during many discussions where their expertise on the production and distribution of materials associated with the U.S. nuclear test program was most useful in developing this assessment. Also, Dr. Gene Burke, physicist, of the LLNL A
Division was very generous of his time for discussions about the use of the materials and their probable distribution.

This work was performed under the auspices of the U.S. Department of Energy, the University of California at the Lawrence Livermore National Laboratory under contract No. W-7405-Eng-48.

\section{References}

Barnes, J. W., E. J. Lang, and H. A. Potratz (1956), "Ratio of Ionium to Uranium in Coral Limestone," Science 124: 175-176.

Bowen, V. T., V. E. Noshkin, H. D. Livingston, and H. L. Volchok (1980), "Fallout Radionuclides in the Pacific Ocean: Vertical and Horizontal Distributions, Largely from GEOSECS Stations," Earth Plant. Sci. Ltr. 49: 411-434.

Broecker, W. S. and D. L. Thurber (1965), "Uranium-Series Dating of Corals and Oolites from Bahaman and Florida Key Limestones," Science 149: 58-60.
Glasstone, S. (1962), The Effects of Nuclear Weapons, USAEC, Washington, DC.

International Atomic Energy Agency (1985), "Sediment Kds and Concentration Factors for Radionuclides in the Marine Environment," IAEA Technical Report Series No. 247, International Atomic Energy Agency, Vienna, Austria.

International Atomic Energy Agency (1998), AQCS Catalogue for Reference Materials and Intercomparison Exercises 1998/1999, Analytical Quality Control Services, IAEA, Vienna, Austria. 
Lougheed, R. (2001), Private communication, Lawrence Livermore National Laboratory, Radiochemistry Division, Livermore, CA.

Marshall, R. P. and W. R. Schell (1974), Distribution of Alpha-emitting Radionuclides in Sediments of Bikini Atoll Lagoon, University of Washington, College of Fisheries, Laboratory of Radiation Ecology, Seattle, WA, RLO2225-T18-12.

Moody, K. (2001), Private communication, Lawrence Livermore National Laboratory, Radiochemistry Division, Livermore, CA.

Nelson, V. A. (1979a), Radiological Survey of Plants, Animals, and Soil in Micronesia, University of Washington, College of Fisheries, Laboratory of Radiation Ecology, Seattle, WA, NVO-269-35.

Nelson, V. A. (1979b), Radiological survey of Plants, Animals, and Soil at Five Atolls in the Marshall Islands, University of Washington, College of Fisheries, Laboratory of Radiation Ecology, NVO269-36.

Noshkin, V. E., W. L. Robison, K. M. Wong, and R. J. Eagle (1998), “Behavior of Plutonium Isotopes in the Marine Environment of Enewetak Atoll," J. Radioanal. and Nuc. Chem. 234: 243-249.

Park, P. K., D. R. Kester, I. W. Duedall, and B. H. Ketchum (1983), Eds., Wastes in the Ocean, Volume 3, Radioactive Wastes and the Ocean, John Wiley \& Sons, New York, NY.

Robison, W. L., M. E. Mount, W. A. Phillips, M. L. Stuart, S. E. Thompson, C. L. Conrado, and A. C. Stoker (1982), An Updated Radiological Dose Assessment of Bikini and Eneu Islands at Bikini Atoll, Lawrence Livermore National Laboratory, Livermore, CA, UCRL53225.
Robison, W. L., C. L. Conrado, and W. A. Phillips (1987), Enjebi Island Dose Assessment, Lawrence Livermore National Laboratory, Livermore, CA, UCRL-53805.

Robison, W. L., C. L. Conrado, and M. L. Stuart (1988), Radiological Conditions at Bikini Atoll: Radionuclide Concentrations in Vegetation, Soil, Animals, Cistern Water, and Ground Water, Lawrence Livermore National Laboratory, Livermore, CA, UCRL-53840.

Robison, W. L., C. L. Conrado, and K. T. Bogen (1994), An Updated Dose Assessment for Rongelap Island, Lawrence Livermore National Laboratory, Livermore, CA, UCRL-LR-107036.

Robison, W. L., K. T. Bogen, and C. L. Conrado (1997), “An Updated Dose Assessment for Resettlement Options at Bikini Atoll-A U.S. Nuclear Test Site," Health Physics 73(1): 100-114.

Robison, W. L. and V. E. Noshkin (1999), "Radionuclide Characterization and Associated Dose from Long-Lived Radionuclides in Close-In Fallout Delivered to the Marine Environment at Bikini and Enewetak Atolls," Sci. of the Total Env. 237/238: 311-327.

Robison, W. L., C. L. Conrado, and K. T. Bogen (1999), Utirik Atoll Dose Assessment, Lawrence Livermore National Laboratory, Livermore, CA, UCRL-LR135953.

Shinn, J. H., D. N. Homan, and W. L. Robison (1997), "Resuspension Studies in the Marshall Islands," Health Physics 73(1): 248-257.

Simon, S. L. and Robison, W. L. (1997) “A Compilation of Nuclear Weapons Test Detonation Data form U. S. Pacific Ocean Tests," Health Physics 73(1): 258-264. 
Tatsumoto, M. and E. D. Goldberg (1959), “Some Aspects of the Marine Geochemistry of Uranium," Geochimica et Cosmochimica Acta 17: 201-208.

Thurber, D. L., W. S. Broecker, R. L. Blanchard, and H. A. Potratz (1965), "UraniumSeries Ages of Pacific Atoll Coral," Science 149: 55-58.

United Nations Scientific Committee on the Effects of Atomic Radiation (2000), UNSEAR 2000 Report to the General Assembly, with annexes, Volume 1: Sources, United Nations, New York, NY.
United States Atomic Energy Commission (1973), Enewetak Radiological Survey, Vol. I, II, III, Nevada Operations Office, Las Vegas, NV.

Veeh, H. H. and K. K. Turekian (1968), “Cobalt, Silver, and Uranium Concentrations of Reef-Building Corals in the Pacific Ocean," Limno. Oceano. 13: 304-308.

\section{Glossary of Terms}

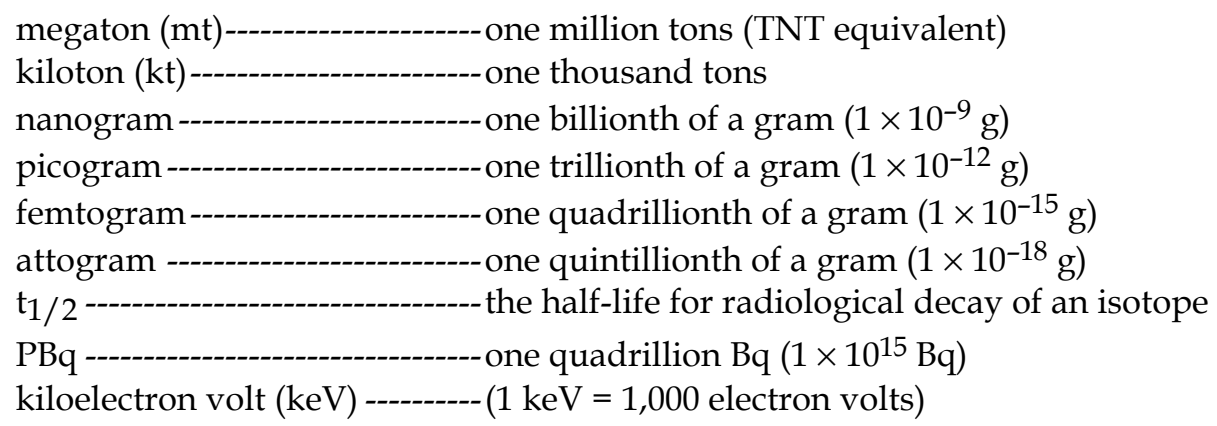

